CONTRERAS CHAIMOVICH, Lautaro: "Mandato constitucional de determinación y

delitos imprudentes de homicidio y lesiones".

Polít. Crim. Vol. 16, № 31 (Junio 2021), Art. 7, pp. 164-196.

[http://politcrim.com/wp-content/uploads/2021/05/Vol16N31A7.pdf]

\title{
Mandato constitucional de determinación y delitos imprudentes de homicidio y lesiones*
}

Principle of Legality in Criminal Law and Crimes of Negligent Homicide and Injuries

\author{
Lautaro Contreras Chaimovich \\ Profesor de Derecho penal, Universidad de Chile \\ Legum magister y doctor por la Albert-Ludwigs-Universität (Alemania) \\ lcontreras@derecho.uchile.cl \\ http://orcid.org/0000-0002-9488-9976
}

\section{Resumen}

El presente trabajo busca dar respuesta a la pregunta de si la regulación de los delitos imprudentes de homicidio y lesiones, contemplada en el Código Penal chileno, satisface el mandato constitucional de determinación, previsto en el inc. final del art. 19 n³ de la Constitución Política chilena. Para ello, se analiza la finalidad del mandato de determinación y las exigencias que impone al legislador penal. Seguidamente, se exponen y revisan críticamente los argumentos de los autores del Derecho alemán que han planteado la inconstitucionalidad de los delitos imprudentes de homicidio y lesiones. Finalmente, se examina la compatibilidad de los tipos imprudentes de homicidio y lesiones, previstos en el Código Penal chileno, con el mandato constitucional de determinación.

Palabras clave: Delitos imprudentes, homicidio y lesiones culposos, mandato de determinación, mandato de taxatividad, mandato de tipicidad, normas de conducta y normas de sanción.

\begin{abstract}
The article addresses the question of whether the regulation of the crimes of negligent homicide and injuries, contemplated in the Chilean Criminal Code, satisfies the constitutional principle of legality in criminal law, established in the final subparagraph of article $19 \mathrm{n}^{\circ} 3$ of the Political Constitution. This article analyses the purpose of the principle of legality, as well as the requirements that it imposes over the legislator of criminal law. Then, it exposes and critically review the arguments of scholars who, in the context of German law, have proposed the unconstitutionality of the crimes of negligent homicide and injuries. Finally, this article examines the compatibility between the crimes of negligent homicide and injuries,
\end{abstract}

\footnotetext{
*Este trabajo ha sido desarrollado en el marco del proyecto Fondecyt de Iniciación No 11160021, "La determinación del deber de cuidado en los delitos culposos de resultado". El autor agradece a José Leyton Jiménez y a Javier Sola por sus valiosas observaciones a la versión preliminar de este trabajo, y a los ayudantes Borja Bernasconi, Macarena Muñoz y Belén Tomic por la búsqueda de material bibliográfico.
} 


\section{Polít. Crim. Vol. 16, № 31 (Junio 2021), Art. 7, pp. 164-196. [http://politcrim.com/wp-content/uploads/2021/05/Vol16N31A7.pdf]}

established in the Chilean Criminal Code, and the constitutional principle of legality in criminal law.

Keywords: criminal negligence, negligent homicide and injuries, principle of legality, criminal conduct and criminal sanction.

\section{Introducción}

Para el castigo penal de un comportamiento no basta con que se reúnan presupuestos materiales de legitimación; es esencial, además, que se cumpla la exigencia formal que impone el principio de legalidad, esto es, que una norma legal de sanción califique la conducta infractora como delictiva. ${ }^{1}$ Por ello, aunque un comportamiento se aparte de una norma de conducta elemental, fundada social-éticamente, y la intervención penal a través de la imposición de una sanción proporcional aparezca como necesaria, si la conducta no aparece comprendida por el sentido literal posible de alguna norma legal de sanción, no será procedente castigo alguno.

Una de las garantías básicas del principio de legalidad consiste en el mandato de determinación, de taxatividad o de tipicidad, ${ }^{2}$ conforme al cual el legislador penal debe establecer normas de sanción suficientemente determinadas, excluyendo disposiciones imprecisas que puedan ser manipuladas por el órgano de persecución o los tribunales con competencia en lo criminal. ${ }^{3}$ Este mandato, previsto en el inc. final del art. 19 no3 de la Constitución Política de la República, si bien se dirige al Poder Legislativo, en los últimos años la jurisprudencia y doctrina comparadas han destacado que también los tribunales penales podrían ser sus destinatarios. ${ }^{4}$ En virtud de esta garantía, únicamente el legislador democrático está facultado para decidir los contornos de la punibilidad, razón por la cual debe evitar la utilización de términos vagos en las normas de sanción, puesto que de lo contrario se corre el riesgo cierto de que la decisión relativa al merecimiento de pena recaiga en los fiscales o jueces penales que tengan a su cargo la interpretación de esas normas. ${ }^{5}$ De otro lado, el mandato de determinación cumpliría una función relevante al orientar la conducta del ciudadano, puesto que, al estar dotadas las leyes penales de la debida publicidad

${ }^{1}$ FRISCH (1993), p. 248; FREUND y ROSTALSKI (2019), $§ 1 \mathrm{~nm} .70$. Sobre el principio de legalidad en el Derecho chileno véase MATUS y RAMÍREZ (2019), pp. 77 y ss.; SILVA (2006), pp. 173 y ss.; VERDUGO et al. (1997), p. 227; VIVANCO (2007), pp. 354 y ss.

${ }^{2}$ En la jurisprudencia constitucional chilena no es posible encontrar una expresión uniforme para aludir al mandato de determinación. Así, se habla de "mandato de determinación" (rol 3306-17-INA, 16 noviembre de 2017, considerando $47^{\circ}$ ), "principio de legalidad en su manifestación de tipicidad o, mejor dicho, de taxatividad" (roles 2773 (2817, 2849 y 2859)-15-INA, acumulados, 28 enero de 2016, considerando $14^{\circ}$ ), "mandato de tipificación" (roles 2773 (2817, 2849 y 2859)-15-INA, acumulados, 28 enero de 2016, considerando $7^{\circ}$ ), "principio de taxatividad o legalidad penal en sentido estricto" (rol 3306-17-INA, 16 noviembre de 2017, considerando $16^{\circ}$ ), "principio de tipicidad" (rol 3630-17-INA, 17 de mayo de 2018, considerando $4^{\circ}$ ).

${ }^{3}$ Acerca del significado básico del mandato de determinación véase DANNECKER (2007), nm. 110; MISSERONI (1993 - 1994), p. 211.

${ }^{4}$ BVerfGE 126, 170, 198 y s.; KUHLEN (2013), pp. 59 y ss. Al respecto, véase 1.2.5.

${ }^{5}$ Confróntese sentencia del Tribunal Constitucional chileno de 20 de mayo de 2010, rol 1351-09-INA, considerando $40^{\circ}$ (“( (...) el principio de legalidad impide al legislador describir indeterminadamente la conducta punible y a su vez le prohíbe al juez definirla (...)"; la cursiva es nuestra). Véase también KIRSCH (2014), p. 22. 
y conocimiento general, estas permitirían reconocer fácilmente cuál es el comportamiento prohibido o mandado penalmente, y cuál, en cambio, es el lícito. ${ }^{6}$

En materia de homicidio y lesiones culposos, un grupo de importantes autores del derecho comparado postula que estos tipos no cumplirían la función de orientación de conductas recién indicada, pues se tratarían de normas legales de sanción de carácter indeterminado y, por tanto, contrarias al mandato de taxatividad. ${ }^{7}$ Afirman estos autores que tales tipos no permitirían reconocer ex ante el ámbito del comportamiento punible, al no precisarse en ellos cuáles infracciones a deberes de cuidado permitirían fundar una punibilidad culposa. ${ }^{8}$ Prosiguen y señalan que sobre los ciudadanos pendería siempre la espada de Damocles del Derecho Penal, sin que puedan evitar la sanción desplegando conductas ajustadas al cuidado debido. ${ }^{9}$ En definitiva, en los homicidios y lesiones corporales imprudentes, la determinación del comportamiento típico quedaría entregada (ilegítimamente) a la labor de concreción de la jurisprudencia y doctrina, ${ }^{10}$ y no al Poder Legislativo.

Si bien los reparos a la constitucionalidad de los delitos imprudentes de homicidio y lesiones se han planteado en el contexto de los tipos previstos en los $\S \S 222$ y 229 del Código Penal alemán (en adelante indistintamente "StGB"), la mera lectura de los delitos contemplados en los artículos 490 a 492, en relación, por ejemplo, a los artículos 391 n² o 399, todos del Código Penal chileno (en adelante indistintamente "CP"), permite concluir que las disposiciones nacionales no son más determinadas o precisas que sus equivalentes alemanas, por lo que en nuestro medio también se podrían plantear dudas sobre la constitucionalidad de los ilícitos referidos.

Los efectos que tendría estimar inconstitucionales las disposiciones chilenas recién indicadas serían de una gran trascendencia práctica. Las conductas culposas que los jueces habitualmente subsumen en los artículos 490 a 492 del CP, en relación con los respectivos delitos contra las personas, no serían susceptibles de ser sancionadas, al faltar un presupuesto formal básico para imponer legítimamente el castigo. Así, por ejemplo, el médico que, infringiendo gravemente la lex artis, ha delegado la aplicación de una inyección intravenosa en un auxiliar paramédico no capacitado para realizar tal procedimiento, provocando la muerte del paciente, ${ }^{11}$ no podría ser penalmente responsable por homicidio imprudente, en virtud del art. 491 inc. $1^{\circ}$, en relación con el art. 391 n $^{\circ} 2$, ambos del CP. Y así, toda sentencia condenatoria que se dictara en casos similares a este representaría un verdadero "injusto judicial", al fundarse en una norma inconstitucional, es decir, inválida. ${ }^{12}$ Por ello, cualquier tribunal con competencia penal que conociera de un hecho como el descrito debería promover

\footnotetext{
${ }^{6}$ La idea de que las normas de sanción penal constituyan mecanismos idóneos para orientar la conducta de los ciudadanos, permitiéndoles eliminar o disminuir hasta límites tolerables los riesgos para bienes jurídicos, es problemática; al respecto véase 1.1.2.

${ }^{7}$ En este sentido DUTTGE (2017), nm. 33 y ss.; DUTTGE (2014), p. 266; DUTTGE (2003), pp. 26 y ss.; DUTTGE (2001), pp. 202 y ss.; SCHMITZ (2017), nm. 58 y s.; SCHMITZ (2010), pp. 182 y 198; COLOMBI (2005), pp. 33 y ss., 41; WALTHER (2005), p. 687; en una línea similar a los autores anteriores véase HASSEMER y KARGL (2017), nm. 23.

${ }^{8}$ Confróntese SCHMITZ (2010), pp. 183 y s.

${ }^{9}$ DUTTGE (2017), nm. 37.

${ }^{10}$ DUTTGE (2017), nm. 33.

${ }^{11}$ Véase sentencia de la Corte Suprema de 10 de marzo de 2011, Rol n. ${ }^{\circ}$ 2.285-2010.

12 Confróntese HERZBERG (2015), p. 423.
} 


\section{Polít. Crim. Vol. 16, № 31 (Junio 2021), Art. 7, pp. 164-196. [http://politcrim.com/wp-content/uploads/2021/05/Vol16N31A7.pdf]}

un requerimiento de inaplicabilidad,,$^{13}$ y el Tribunal Constitucional tendría que declarar que una aplicación en el proceso criminal de la norma cuestionada sería contraria al mandato de determinación.

Teniendo en cuenta las trascendentales consecuencias que tendría estimar inconstitucionales los delitos imprudentes de homicidio y lesiones, previstos en el CP, el presente trabajo pretende dar respuesta a la pregunta de si estos ilícitos cumplen el mandato de determinación. Para ello, en primer lugar, se explicarán las finalidades que esta garantía constitucional persigue, revisando posteriormente las exigencias mínimas que tiene que satisfacer el legislador para dictar tipos penales suficientemente determinados (véase 1.). A continuación, se expondrán y analizarán de forma crítica las argumentaciones de los autores que consideran inconstitucionales los delitos imprudentes de homicidio y lesiones, en atención a la supuesta falta de precisión de los términos legales que emplean (véase 2.). Finalmente, se abordará derechamente la cuestión relativa a la constitucionalidad de los tipos chilenos imprudentes de homicidio y lesiones (véase 3.).

\section{Finalidad del mandato constitucional de determinación y exigencias que impone al legislador}

La respuesta a la pregunta de si los delitos culposos de homicidio y lesiones corporales, previstos en el Código Penal, cumplen el mandato constitucional de determinación, presupone aclarar cuáles son las finalidades que esta garantía persigue en el contexto del principio de legalidad, y qué exigencias concretas impone al legislador penal. Solo esclareciendo estos aspectos, es posible analizar la compatibilidad de tales delitos con el mandato en cuestión.

\subsection{Finalidad del mandato de determinación}

\subsubsection{Cuestiones previas}

Según el principio de legalidad, la punibilidad de un hecho, así como la clase y gravedad de la pena aplicable, tienen que establecerse por ley. Este principio fue codificado por vez primera en el art. $8^{\circ}$ de la Declaración de los Derechos del Hombre y del Ciudadano, de 1789, y representa una conquista de la Ilustración. La idea que subyace tras este principio es que el individuo solo le debe fidelidad al Derecho creado por el Estado en aquellos ámbitos en que aquel se ha obligado a través del contrato social; por consiguiente, únicamente la ley general es garantía frente a penas arbitrarias o sorpresivas. ${ }^{14}$

Para cumplir el principio de legalidad no basta con que una ley castigue un delito con una pena de determinada clase y gravedad; es indispensable, además, que la ley predetermine con suficiente exactitud la clase de comportamiento que debe realizarse u omitirse para imponer la sanción. Solo así se puede garantizar que la aplicación del Derecho al caso concreto esté guiada efectivamente por la ley, y los tribunales penales no impongan un castigo arbitrariamente, sobre la base de intuiciones de merecimiento de sanción surgidas de las

\footnotetext{
${ }^{13}$ Confróntese arts. 79 y ss. de la Ley $n{ }^{\circ} 17.997$.

${ }^{14}$ En este sentido, correctamente, HUFEN (2014), § $21 \mathrm{~nm} .52$.
} 
circunstancias del caso concreto. ${ }^{15}$ La predeterminación, con suficiente exactitud, de la clase de comportamiento que debe realizarse u omitirse para imponer una pena, se garantiza en nuestro ordenamiento jurídico a través de la exigencia de taxatividad de los tipos penales, prevista en el inc. final del art. 19 n³ 3 de la Constitución Política: "Ninguna ley podrá establecer penas sin que la conducta que se sanciona esté expresamente descrita en ella".

\subsubsection{La protección de la confianza como objetivo del mandato de determinación}

Para la jurisprudencia constitucional y un sector mayoritario de la doctrina, la finalidad del mandato de determinación consistiría en proteger la confianza como componente necesario del Estado de Derecho. En este sentido, el Tribunal Constitucional chileno ha declarado que solo cuando el comportamiento punible está descrito expresamente en la ley, los ciudadanos pueden tener "suficiente noticia previa acerca de la conducta que les resultará exigible" y cuya inobservancia está castigada con pena, ${ }^{16}$ agregando que una descripción legal expresa del comportamiento es el presupuesto indispensable para conocer el "alcance de la amenaza penal", así como el "ámbito de las conductas prohibidas". ${ }^{17}$

En un sentido similar se han pronunciado numerosos autores, para quienes leyes penales determinadas permitirían reconocer sin dificultad cuáles son las prohibiciones y los mandatos protegidos penalmente $\mathrm{y}$, por consiguiente, qué conductas generan responsabilidad criminal. ${ }^{18}$ Según estos autores, el ciudadano que cumple el deber jurídico exigido por la ley penal podría legítimamente confiar en que no será castigado; esa confianza le permite ejercer plenamente la libertad garantizada en la Constitución. ${ }^{19}$

La noción de protección de la confianza como finalidad del mandato de determinación es problemática. Ciertamente, el que las leyes constituyan un mecanismo idóneo para que los ciudadanos se informen acerca de las prohibiciones y mandatos protegidos penalmente, parece ser una afirmación ajena a la realidad. ${ }^{20}$ Muy pocos legos han leído algún precepto del

\footnotetext{
15 Así DUTGGE (2014), p. 263. Asimismo, el mandato de determinación también garantiza la plena vigencia de las prohibiciones de retroactividad y de analogía. En efecto, una norma penal imprecisa permite abarcar desde el inicio de su vigencia un sinnúmero de casos posibles, por lo que si un juez considera que cierta conducta merece ser sancionada penalmente, podrá recurrir a tal norma, sin que sea necesario aplicar retroactivamente otro tipo penal; la norma imprecisa permitirá abarcarlo casi todo (así KARGL (2019), nm. 339). Por otra parte, un tipo penal impreciso hace perder toda eficacia a la prohibición de analogía, puesto que le otorga a los jueces un muy amplio margen de decisión, que hace innecesaria una interpretación analógica del tipo para sancionar conductas que se estiman merecedoras de pena (en este sentido, KIRSCH (2014), p. 29).

${ }^{16}$ Sentencia del Tribunal Constitucional de 28 enero de 2016, roles 2773 (2817, 2849 y 2859)-15-INA, acumulados, considerando $10^{\circ}$.

${ }^{17}$ Sentencia del Tribunal Constitucional de 16 noviembre de 2017, rol 3306-17-INA, considerandos 15 y 16 ; destacan también la idea de la protección de la confianza las sentencias del Tribunal Constitucional rol 332917-INA, 23 agosto de 2018, considerando 20 ; rol 3630-17-INA, 17 de mayo de 2018, considerando $8^{\circ}$; rol 5304-18-INA, 27 de junio de 2019, considerando $18^{\circ}$. En la jurisprudencia constitucional alemana, esta misma idea se puede encontrar, por ejemplo, en BVerfGE 75, 329, 341; 126, 170, 194 y s.

${ }^{18}$ Véase, entre otros, CURY (1988), p. 14; MATUS y RAMÍREZ (2019), p. 82; OSSANDÓN (2009), pp. 524 y s.; en el Derecho alemán, véase por ejemplo FISCHER (2018), § 1 nm. 1; REMMERT (2017), nm. 31; ROXIN (2013), p. 114.

${ }^{19}$ Por todos, KARGL (2019), nm. 345.

${ }^{20}$ RANSIEK (1988), p. 14; confróntese también FERNÁNDEZ (2014), p. 211, así como VAN WEEZEL (2011), p. 10.
} 


\section{Polít. Crim. Vol. 16, № 31 (Junio 2021), Art. 7, pp. 164-196. [http://politcrim.com/wp-content/uploads/2021/05/Vol16N31A7.pdf]}

Código Penal, y es más que dudoso que, aquellos que lo han hecho, hayan comprendido verdaderamente su tenor o los vínculos que muchas veces existen entre las normas de sanción penal y el complejo orden primario de conducta. ${ }^{21}$ Además, la idea de la confianza del sujeto en no ser castigado, basada en la "noticia previa" de la amenaza penal que proporcionaría la ley, puede llevar a un debilitamiento del principio de legalidad. Y es que, si lo realmente decisivo es la existencia de información clara para el ciudadano sobre aquellos comportamientos castigados con pena, no hay razón alguna para que tal información no pueda estar contenida en fuentes distintas a la ley, como, por ejemplo, en un mero acto administrativo. ${ }^{22}$ Por otra parte, condicionar la validez de una norma de sanción penal a que el sujeto pueda, por medio de ella, conocer los comportamientos sancionados con pena, es inconsistente con la dogmática del error de prohibición. ${ }^{23}$ En efecto, según la postura dominante, la previsibilidad de realización de un injusto penal no constituye un presupuesto de la culpabilidad; para afirmar la conciencia del injusto, basta con que la persona haya podido conocer la prohibición jurídica de su conducta. ${ }^{24}$ Por consiguiente, si el sujeto conocía tal prohibición, pero partía del supuesto equivocado de que su conducta no era punible, no le beneficiará error de prohibición alguno.

En realidad, la legítima confianza en favor del ciudadano no se logra a través de leyes penales, sino mediante un sistema adecuado de deberes jurídicos, es decir, de normas de conducta que le indiquen al sujeto cómo actuar en una situación concreta, para así eliminar o disminuir riesgos respecto de bienes jurídicos. ${ }^{25} \mathrm{El}$ quebrantamiento de una norma de conducta, que satisfaga el principio de proporcionalidad, constituye el requisito básico de cualquier hecho punible. ${ }^{26}$ En efecto, la sanción penal presupone siempre el quebrantamiento de un deber jurídico que pueda ser legitimado, y cuya vigencia tiene que ser estabilizada por medio de la pena; tal quebrantamiento representa el comportamiento típico del respectivo delito. Como para imponer la sanción es indispensable haber infringido una norma de conducta que regía para la situación concreta en que se encontraba el sujeto, los ciudadanos pueden confiar en que, si la cumplen, su actuar no será desaprobado ni, en consecuencia, castigado penalmente.

Por otra parte, como los únicos deberes jurídicos que permiten enjuiciar el carácter tolerado o desaprobado de un comportamiento son aquellos que regían al momento en que este se realizó u omitió, los ciudadanos pueden también confiar en que sus conductas no serán desaprobadas retroactivamente $y$, con ello, castigadas. ${ }^{27}$ Lo anterior asegura que ningún

\footnotetext{
${ }^{21}$ Por orden primario de conducta entendemos aquella parte del ordenamiento jurídico integrada por prohibiciones y mandatos, cuya finalidad inmediata es la protección de bienes jurídicos. Junto al orden primario de conducta se encuentra el orden secundario de sanción, compuesto por normas que prevén consecuencias jurídicas en caso de que se infrinjan determinadas prohibiciones o mandatos. Sobre la diferencia entre orden primario y secundario véase MURMANN (2017), $§ 8 \mathrm{~nm} .6$ y s.

${ }^{22}$ Confróntese KIRSCH (2014), pp. 64 y s.

23 Así RANSIEK (1988), p. 21.

${ }^{24}$ Sobre el estado de la discusión acerca del injusto como punto de referencia del error de prohibición véase MURMANN (2017), § $26 \mathrm{~nm} .47$ y s.

${ }^{25}$ FREUND (2013), p. 36.

${ }^{26}$ En tanto las normas de conducta representan una limitación a la libertad general de actuación (o a otra libertad asegurada constitucionalmente), tienen que legitimarse desde el punto de vista constitucional. Por eso, deben representar siempre un medio idóneo, necesario y proporcional en sentido estricto para proteger bienes jurídicos. En este sentido FREUND y ROSTALSKI (2019), § 1 nm. 55 y ss.

${ }^{27}$ Confróntese FREUND (2013), p. 36.
} 
inocente sea sorprendido por el Derecho Penal; para lograr esto no es necesario el principio de legalidad. ${ }^{28}$ Por las razones expuestas, debe rechazarse la idea de la protección de la confianza como finalidad del mandato constitucional de determinación.

1.1.3. La necesaria separación de competencias estatales en la intervención punitiva como objetivo del mandato de determinación

La finalidad del mandato de determinación no consiste en resguardar la confianza de los ciudadanos, sino en garantizar la necesaria separación de competencias entre los poderes del Estado respecto de las tareas de creación de tipos penales, por una parte, y de declaración de culpabilidad e imposición de pena en casos concretos, por otra. ${ }^{29}$ Ciertamente, la aplicación del Derecho Penal representa la injerencia estatal más grave en los derechos fundamentales de los individuos; luego, para condenar e imponer una sanción criminal, los tribunales con competencia penal deben estar habilitados expresamente para ello, por medio de una ley aprobada por el parlamento. ${ }^{30}$ Únicamente este, en tanto órgano legitimado por el pueblo de manera directa, a través de elecciones libres y periódicas, garantiza un debate público y una decisión adoptada por la mayoría en el proceso de creación de tipos penales. ${ }^{31}$ Además, la tarea de aprobar leyes penales nunca puede ser delegada en el Poder Ejecutivo. ${ }^{32}$

Ahora bien, mientras que el legislativo es el poder competente para crear tipos delictivos, los tribunales penales son los únicos órganos facultados para aplicarlos a casos concretos, declarando la culpabilidad del autor e imponiéndole una pena. La competencia exclusiva de los tribunales en la tarea de aplicar la ley penal se justifica plenamente, puesto que la sujeción de los órganos estatales a la ley no tendría eficacia alguna si el mismo poder facultado para dictar tipos penales se encargara de su interpretación y aplicación a constelaciones fácticas concretas. ${ }^{33}$ La participación de (al menos) dos poderes del Estado independientes entre sí en las tareas de creación de tipos penales, por una parte, y de declaración de culpabilidad e imposición de pena en casos concretos, por otra, garantiza una intervención punitiva estatal legítima y objetiva. ${ }^{34}$

La necesaria separación de competencias respecto de las tareas de creación y de aplicación de tipos delictivos exige que el Poder Legislativo se abstenga de establecer la conducta punible teniendo a la vista hechos ocurridos, pero aún por juzgar, ni como medida contra autores ya conocidos. ${ }^{35} \mathrm{Si}$ lo hiciera, estaría actuando como cuasi-juez, puesto que adoptaría

\footnotetext{
${ }^{28}$ Confróntese FREUND (2019), p. 5; FREUND (2013), p. 36.

${ }^{29}$ Confróntese FREUND (2013), p. 37 y s., 41; RANSIEK (1988), pp. 40 y ss.; DUTTGE (2003), p. 17.

${ }^{30}$ Véase, entre otros, GRÜNWALD (1964), pp. 13 y s.; KIRSCH (2014), p. 60.

${ }^{31}$ NAVARRO (2010), p. 36.

${ }^{32}$ Véase art. 64 inc. $2^{\circ}$ de la Constitución Política de la República. El Poder Ejecutivo únicamente está facultado para concretar los deberes de conducta que rigen en situaciones específicas (confróntese FREUND y ROSTALSKI (2016), pp. 449 y ss.). En cambio, la determinación de la clase o género de infracciones a normas de conducta que tienen que ser castigadas penalmente es de competencia exclusiva del Parlamento (véase 1.2.6). Expresado de otra forma: el Poder Ejecutivo solo está facultado para fijar cuáles son las conductas contrarias a deber, no siendo competente para establecer cuáles son las conductas contrarias a deber punibles.

${ }^{33}$ Confróntese ROXIN (2013), p. 115.

${ }^{34}$ Confróntese FREUND (2013), p. 37.

${ }^{35}$ Este es el fundamento de la prohibición de retroactividad de la ley penal. Confróntese JAKOBS (1991), pp. 67 y ss.
} 


\section{Polít. Crim. Vol. 16, № 31 (Junio 2021), Art. 7, pp. 164-196. [http://politcrim.com/wp-content/uploads/2021/05/Vol16N31A7.pdf]}

decisiones sobre casos determinados que ya han tenido lugar. ${ }^{36}$ Luego, el legislativo tiene que dictar normas de sanción penal que rijan para cierta clase de casos futuros, empleando elementos típicos abstracto-generales; de este modo, se toma la necesaria distancia respecto de los hechos efectivos que puedan acontecer, asegurándose la debida objetividad. ${ }^{37}$ Por otra parte, los tribunales penales, llamados a decidir los casos concretos, no pueden actuar como si fueran cuasi-legisladores. Por ello, para declarar la culpabilidad de un sujeto e imponerle una pena requieren de un fundamento habilitante para intervenir, es decir, de una norma legal de sanción. ${ }^{38}$ Pero, además, esta norma tiene que ser suficientemente precisa o determinada, para así vincular efectivamente a los jueces penales y evitar delegaciones subrepticias en la decisión democrática acerca de cuál debe ser el injusto punible. ${ }^{39}$ De este modo, la exigencia de taxatividad resulta esencial para garantizar la necesaria separación de competencias ya mencionada.

Habiendo aclarado cuál es la finalidad que cumple el mandato de determinación, corresponde abordar las concretas exigencias que este impone al legislador.

\subsection{Las exigencias que impone el mandato de determinación al legislador penal}

\subsubsection{Los límites inmanentes de la capacidad de rendimiento del mandato de determinación}

La respuesta a la pregunta relativa a cuál es la medida de taxatividad que una ley penal tiene que alcanzar para que el legislador cumpla el mandato de determinación, exige reconocer la existencia de límites inmanentes de esta manifestación del principio de legalidad, los cuales se explican ya por la característica esencial de toda ley. Efectivamente, en tanto norma jurídica de carácter general, la ley no puede abarcar un caso específico, sino una multitud de constelaciones fácticas de naturaleza similar. ${ }^{40}$ Ello hace indispensable una cierta medida de amplitud semántica en los términos legales empleados. ${ }^{41}$

Además, la ambigüedad intrínseca del lenguaje impide la plena realización del mandato de determinación. Ciertamente, salvo indicaciones numéricas (ejemplo: límites temporales de las penas privativas de libertad) o términos relacionales (ejemplo: vínculos de parentesco), el sentido de los conceptos jurídicos no puede ser fijado de modo absolutamente preciso. ${ }^{42}$ Todos los términos que contiene una ley admiten distintas interpretaciones, puesto que son usados cotidianamente en diversos contextos, según reglas semánticas propias, y expresan cualidades diferentes. ${ }^{43}$

\footnotetext{
${ }^{36}$ Confróntese SCHÜNEMANN (1978), p. 24.

37 Así, FREUND (2013), p. 37.

${ }^{38}$ FREUND (2013), p. 37 incluyendo nota al pie 7.

${ }^{39}$ Así, NAVARRO (2010), pp. 37 y s.

${ }^{40}$ Confróntese art. $63 \mathrm{n}^{\circ} 20$ de la Constitución. Nuestro Tribunal Constitucional ha declarado en este orden de ideas que: “(...) la descripción típica acabada y plena constituye un ideal, limitado en la práctica por la (...) generalidad de la norma (...)" (roles 2773 (2817, 2849 y 2859)-15-INA, acumulados, 28 enero de 2016, considerando $14^{\circ}$ ).

${ }^{41}$ KARGL (2019), nm. 352; KIRSCH (2014), p. 131.

42 Véase ENGISCH (2010), p. 193; HASSEMER y KARGL (2017), nm. 20. Destacan también la vaguedad del lenguaje como límite inmanente de la capacidad de rendimiento del mandato de taxatividad, OSSANDÓN (2009), pp. 66 y ss.; MATUS y RAMÍREZ (2015), pp. 196 y s.

${ }^{43}$ KARGL (2019), nm. 354.
} 
Otro límite inmanente del mandato de determinación obedece a que, en el momento de dictar la ley, el legislador no está en condiciones de prever el conjunto de cambios sociales, económicos, técnicos, etc., ni tampoco las particularidades de todos aquellos casos que tendrán que ser enjuiciados de acuerdo con la normativa dictada. Tal situación importa no detallarla en exceso y conceder ciertos márgenes de actuación al tribunal penal, para que este pueda valorar debidamente los casos y desarrollar oportunamente la voluntad legislativa. ${ }^{44}$

Sin perjuicio de lo señalado, la cuestión decisiva es cuál tiene que ser el umbral de tolerancia frente a estos límites inmanentes de la capacidad de rendimiento del mandato de determinación, esto es, cuál ha de ser el mínimo de taxatividad de la ley penal exigible constitucionalmente al legislador. Al respecto, la jurisprudencia y la doctrina han desarrollado distintos planteamientos, los que serán analizados a continuación.

\subsubsection{El criterio del "núcleo esencial de la conducta" y la preferencia por elementos normativos}

El Tribunal Constitucional chileno ha señalado que el legislador cumple el mandato de determinación cuando al menos el "núcleo esencial de la conducta" sancionada está descrito en el tipo: "(...) la tipicidad de la ley penal exige que el legislador, por medio de su actividad, contemple una descripción medular de la conducta penal. Ello implica que al menos el núcleo esencial de la conducta sancionada esté descrito en forma clara y patente (...)". 45 Recientemente, el Tribunal ha afirmado: “(...) resulta suficiente para adaptar la norma legal al mandato constitucional de tipicidad, con que el legislador trace o dibuje el núcleo esencial del comportamiento punible. No se exige una precisión matemática, sino 'suficientemente clara como para que un hombre corriente pueda conocer aquello que le está mandado o prohibido, a fin de no exponerse a un castigo' $(\ldots)$ ". ${ }^{46}$

Por consiguiente, para el Tribunal Constitucional la taxatividad exige que el legislador describa el aspecto esencial de la conducta punible sin ambigüiedades, esto es, de un modo claro, patente o especificado. Tal descripción debe permitirle al ciudadano conocer las prohibiciones y mandatos que rigen su comportamiento, para así evitar la imposición de una pena.

El criterio del núcleo esencial puede resultar problemático al momento de establecer si el legislador ha cumplido o no el mandato de determinación. En efecto, cuando el Tribunal Constitucional chileno le otorga relevancia al aspecto esencial de la conducta punible,

\footnotetext{
${ }^{44}$ Así DUTGGE (2014), p. 264.

45 Tribunal Constitucional, roles 2773 (2817, 2849 y 2859)-15-INA, acumulados, de 28 enero de 2016 , considerando $10^{\circ}$.

${ }^{46}$ Tribunal Constitucional, rol 3329-17-INA, 23 agosto de 2018, considerando $20^{\circ}$. La cita textual que contiene este pasaje del fallo corresponde a CURY (1988), p. 91. Véase también sentencia del Tribunal Constitucional de 10 de septiembre de 2015, rol 2758-14-INA, considerando $11^{\circ}$. La idea de la descripción del "núcleo esencial de la conducta" como criterio para verificar si la ley cumple el mínimo de taxatividad exigido constitucionalmente, también ha encontrado acogida en la doctrina chilena. Así ETCHEBERRY (1998), p. 85; FERNÁNDEZ (1998), pp. 150 y ss. (quien, sin embargo, pone el acento en el "núcleo esencial de la prohibición", que abarcaría no solo la conducta delictiva, sino también el bien jurídico protegido y la gravedad de su afectación; la determinación del sujeto activo, la culpabilidad y las consecuencias jurídicas del delito); MATUS y RAMÍREZ (2015), pp. 189 y s.
} 


\section{Polít. Crim. Vol. 16, № 31 (Junio 2021), Art. 7, pp. 164-196. [http://politcrim.com/wp-content/uploads/2021/05/Vol16N31A7.pdf]}

entonces se está admitiendo que los aspectos accidentales o accesorios no necesitan estar cubiertos legalmente. Pero si el principio de legalidad exige que el injusto punible esté previsto siempre en una ley, no puede tolerarse una restricción que distinga entre un supuesto "núcleo esencial" de tal injusto y lo que serían sus elementos accidentales, que podrían no estar descritos legalmente. ${ }^{47} \mathrm{La}$ descripción de los elementos accidentales es igualmente imprescindible, puesto que la reserva de ley se refiere al injusto punible en su conjunto, y no solo a su "núcleo esencial". Además, con independencia de que sea legítima semejante restricción del mandato de taxatividad solo a los aspectos esenciales del injusto, las diferencias entre el componente esencial y el accidental de una conducta punible son todo menos que claras. Precisamente, esta falta de claridad ha permitido al Tribunal Constitucional utilizar la idea del "núcleo esencial" como argumento para afirmar y negar, en fallos distintos, la inaplicabilidad de un mismo precepto penal por ser contrario a la exigencia de taxatividad. ${ }^{48}$

Por otra parte, la idea de que el "núcleo esencial" del comportamiento permitiría conocer aquello que está prohibido o mandado, para así no exponerse al castigo penal, no es correcta. Efectivamente, y como ya se señaló, el conocimiento de lo que está mandado o prohibido se logra a través de un sistema legítimo de normas de conducta, cuyo quebrantamiento constituye el requisito básico de todo hecho punible. Este sistema ya asegura que ningún inocente sea sorprendido por el Derecho Penal. ${ }^{49}$

El Tribunal Constitucional chileno también ha señalado que el legislador cumple el mandato de taxatividad cuando el respectivo tipo penal contiene elementos normativos; ${ }^{50}$ en cambio, si el tipo está configurado como una ley penal en blanco, se debe ser especialmente exigente con el legislador para considerar que este ha acatado el mandato referido. ${ }^{51}$ Así, en una sentencia del año 2015 el tribunal indicó: "La existencia de elementos normativos de un tipo penal no tiene que ver con las leyes penales en blanco. En éstas, no hay una descripción completa del injusto típico. En los tipos con elementos normativos, en cambio, se contiene una formulación completa (...)"52. En otra resolución de 2009 señaló: "Mientras el elemento normativo deber ser interpretado por el juez, en la ley penal en blanco la conducta prohibida

\footnotetext{
${ }^{47}$ En un sentido similar GARCÍA (1993), p. 89, quien analiza críticamente la jurisprudencia del Tribunal Constitucional español sobre las leyes penales en blanco.

${ }^{48}$ Así ha ocurrido con el delito de incumplimiento de deberes militares (art. 299 nº 3 del Código de Justicia Militar), donde el criterio del núcleo esencial de la conducta ha servido de fundamento para declarar la inaplicabilidad del precepto en un caso (por ejemplo, rol 5304-18-INA, 27 de junio de 2019, considerando $17^{\circ}$ ) y para declararlo aplicable en otro (por ejemplo, rol 781-07-INA, 27 de septiembre de 2007, considerando 18 ${ }^{\circ}$ ). 49 Así FREUND (2013), p. 36.

${ }^{50}$ Véase Tribunal Constitucional, rol 2716-14-INA, 10 de septiembre de 2015, considerando $18^{\circ}$; rol 1281-08INA, 13 de agosto de 2009, considerando $15^{\circ}$; rol 3306-17-INA, 16 de noviembre de 2017, considerando $31^{\circ}$.

${ }^{51}$ Según nuestro Tribunal Constitucional, las leyes penales en blanco solo son admisibles cuando contienen "una remisión expresa de la ley a las normas reglamentarias, aun cuando la norma de complemento no sea originada en el proceso legislativo, y siempre que sea la norma de rango legal la que describa el núcleo central de la conducta punible" (roles 2773 (2817, 2849 y 2859)-15-INA, acumulados, 28 enero de 2016, considerando $13^{\circ}$.

${ }^{52}$ Sentencia del Tribunal Constitucional, rol 2716-14-INA, 10 de septiembre de 2015, considerando $18^{\circ}$.
} 
debe ser completada por una norma infralegal o la conducta es tan abierta que no se sabe con certeza qué es lo que debe hacerse o no hacerse para no incurrir en castigo." 53 .

Es dudoso que los elementos normativos del tipo deban considerarse siempre compatibles con el mandato de determinación, y que, en cambio, se tenga que asumir una posición escéptica frente a los delitos configurados como normas penales en blanco. En efecto, es preferible que un tipo describa expresamente la clase de infracciones a normas de conducta que tienen que ser sancionadas penalmente, remitiéndose a un reglamento que cumpla la función de detallar esas normas, a que un tipo sea ambiguo respecto de la clase de infracciones a normas de conducta que generan responsabilidad penal, pero contenga uno o más elementos normativos. ${ }^{54}$ Por ello, desde el punto de vista del mandato de taxatividad, es claramente más recomendable la técnica legislativa empleada en el tipo penal previsto en el inc. $1^{\circ}$ del art. $1^{\circ}$ de la Ley $n^{\circ} 20.000$, que, aunque deba ser complementado a través de un reglamento (confróntese art. 63 de la misma ley), fija con precisión la clase de infracciones a normas de conducta que tienen que ser castigadas, que el tipo del art. 373 del Código Penal, disposición que, si bien emplea elementos normativos, describe con una ambigüedad excesiva la acción típica ("ofender de cualquier modo el pudor o las buenas costumbres con hechos de grave escándalo y trascendencia"). ${ }^{55}$

1.2.3. Determinación de la ley penal como base de una interpretación y aplicación confiables de los tipos

Con respecto a la jurisprudencia del Tribunal Constitucional alemán, esta ha sido poco exigente al momento de fijar las condiciones que el mandato de determinación (previsto en el párrafo $2^{o}$ del Art. 103 de la Grundgesetz) impone al legislador. ${ }^{56}$ Este Tribunal ha señalado que al Poder Legislativo no le está vedado emplear conceptos que necesiten ser interpretados por los tribunales, pues en el Derecho Penal existe una necesidad de vaguedad condicionada por el poliformismo de la vida. ${ }^{57}$ Tales conceptos son inobjetables, especialmente cuando constituyen la base de una interpretación y aplicación de la ley confiable; además, es suficiente si una jurisprudencia consolidada puede eliminar las dudas interpretativas y la norma gana determinación por esta vía. ${ }^{58}$

Respecto de las exigencias cualitativas en el grado de taxatividad que el legislador tiene que cumplir, el Tribunal Constitucional alemán acude a la siguiente fórmula: "mientras más grave sea la pena prevista en el correspondiente tipo, más precisos tienen que estar establecidos legalmente los presupuestos de la punibilidad". 59

\footnotetext{
${ }^{53}$ Sentencia del Tribunal Constitucional, rol 1281-08-INA, 13 de agosto de 2009, considerando $15^{\circ}$, y rol 330617-INA, 16 de noviembre de 2017, considerando $31^{\circ}$.

${ }^{54}$ En un sentido similar VAN WEEZEL (2011), p. 109.

${ }^{55}$ Crítico también respecto del tipo del art. 373 del CP, FERNÁNDEZ (2017), p. 655. Otros tipos que también contienen elementos normativos ambiguos son el del art. 403 ter ("trato degradante") y el del art. 494 ter ("acto de significación sexual capaz de provocar una situación objetivamente intimidatoria, hostil o humillante").

${ }^{56}$ Un detallado análisis crítico de la jurisprudencia del Tribunal Constitucional alemán en relación con el mandato de determinación, al menos hasta 1986, en KRAHL (1986), passim.

57 Véase, por ejemplo, BVerfGE 71, 108, 114 s.; 75, 329, 342 s.; 92, 1, 12.

${ }^{58}$ Así, entre otras, BVerfGE 26, 41, 43; 28, 175, 185; 87, 209, 227; 92, 1, 18.

${ }^{59}$ Entre otras BVerfGE 41, 314, 320; 75, 329, 342; 126, 170, 196.
} 


\section{Polít. Crim. Vol. 16, № 31 (Junio 2021), Art. 7, pp. 164-196. [http://politcrim.com/wp-content/uploads/2021/05/Vol16N31A7.pdf]}

La jurisprudencia constitucional alemana relativa al mandato de determinación no está exenta de importantes reparos. Ciertamente, si la finalidad de este mandato consiste en asegurar la debida separación de competencias estatales en las tareas de creación y aplicación de tipos penales, entonces hay que diferenciar claramente la determinación legal de la determinación interpretativa de dichos tipos. ${ }^{60} \mathrm{~A}$ través de la jurisprudencia consolidada no es posible "sanar" la inconstitucionalidad de una ley penal insuficientemente precisa; solo es posible evaluar la taxatividad de una ley considerando su tenor, siendo irrelevante la interpretación que de esta hayan hecho los tribunales. ${ }^{61}$ Además, como la formación de la jurisprudencia requiere años a partir de la entrada en vigor de la ley penal, las sentencias de los tribunales nunca permitirán apreciar si la ley satisfacía el mandato de taxatividad justo antes de su aprobación. ${ }^{62}$ Por ello, la idea de la jurisprudencia consolidada no le permite al legislador comprobar si está creando tipos penales suficientemente determinados.

Tampoco parece ser posible sostener una atenuación de la taxatividad tratándose de delitos con sanciones menos graves. Según el texto constitucional alemán (y también conforme al chileno), el mandato de determinación rige por igual para toda clase de ilícitos, con independencia de la magnitud de la pena que tengan asignada. ${ }^{63}$

\subsubsection{Determinación de la ley penal como mandato de optimización}

La doctrina también ha desarrollado propuestas sobre la medida de taxatividad que un tipo tiene que alcanzar, para que el legislador penal cumpla el mandato de determinación. Así, según Lenckner, tal medida debe fijarse a través de una ponderación de intereses entre la seguridad jurídica y la justicia material. Para este autor, la seguridad jurídica que la exigencia de taxatividad buscaría garantizar, no sería la única finalidad que debe perseguir el legislador penal cuando crea delitos. Este también tendría que buscar la realización de la justicia material en el caso concreto, que es un componente básico del Estado de Derecho, objetivo que exigiría, con cierta frecuencia, la utilización de conceptos que necesitan de complementación valorativa (Wertausfüllungsbedürftige Begriffe ). ${ }^{64}$ Aplicando el principio de interpretación constitucional de concordancia práctica, el legislador penal debería garantizar tanta seguridad jurídica como justicia material cuanto le sea posible. ${ }^{65}$ De esta forma, la exigencia de taxatividad se concibe como un mandato de optimización, que admite concesiones en favor de otros objetivos constitucionales con los cuales puede entrar en conflicto (y que también tienen que ser maximizados). ${ }^{66}$

\footnotetext{
${ }^{60}$ Esto es destacado correctamente por JAKOBS (1991), p. 79, así como por KARGL (2019), nm. 367.

${ }^{61}$ Confróntese COLOMBI (2005), p. 18; DUTTGE (2001), pp. 172 y s.

${ }^{62}$ Confróntese KIRSCH (2014), p. 141.

${ }^{63}$ En este mismo sentido, correctamente, ROXIN (2013), p. 134.

${ }^{64}$ LENCKNER (1968), p. 305.

${ }^{65}$ LENCKNER (1968), p. 305. Una consideración de los intereses en la justicia material, para fijar el grado de taxatividad exigido por el mandato de determinación, parece encontrarse en la sentencia del Tribunal Constitucional chileno de 16 noviembre de 2017, rol 3306-17-INA, considerando $47^{\circ}$.

${ }^{66}$ En favor también de la exigencia de taxatividad como mandato de optimización DANNECKER (2007), nm. 195 y s.; KUHLEN (2007), pp. 95 y s. No excluyendo la posibilidad de entender esa exigencia como un mandato de optimización FERNÁNDEZ (2017), p. 660.
} 
La ponderación entre seguridad jurídica y justicia material para definir el grado de taxatividad de la ley penal también debe ser rechazada. La justicia, en el caso concreto, difícilmente puede promoverse por medio de leyes indeterminadas; si se entiende por justicia material la coincidencia de la solución del caso concreto con las convicciones socio-culturales dominantes, entonces las leyes imprecisas conllevan solo pluralismo valorativo y, con ello, arbitrariedad judicial. ${ }^{67}$ Además, por su propia naturaleza normativa, el mandato de determinación no puede ser ponderado con otros intereses. Ciertamente, el constituyente alemán ya ha realizado una "ponderación previa" tratándose de este mandato, y no ha contemplado ninguna excepción frente al resultado de aquella. ${ }^{68}$ Luego, la exigencia de taxatividad constitucional constituye una verdadera "regla" (en el sentido que a esta expresión le otorga Alexy), es decir, una norma que solo puede ser cumplida o no cumplida, y respecto de la cual no cabe ponderación alguna. ${ }^{69}$

\subsubsection{El mandato de determinación como exigencia dirigida también al juez penal}

Todos los planteamientos revisados hasta ahora parten del supuesto de que el mandato de determinación establece ciertas condiciones que la ley penal tiene que cumplir y, por consiguiente, se trata de una obligación dirigida al legislador. Sin embargo, no son pocos los autores para quienes la exigencia de taxatividad también está destinada a los aplicadores del Derecho, representando una regla de interpretación de la ley penal. ${ }^{70}$ A esta postura se ha adherido una importante sentencia del Tribunal Constitucional alemán, pronunciada el 23 de junio de 2010 y relativa a la determinación del tipo de administración desleal (§266 StGB). En este fallo se afirma que la jurisprudencia está obligada a disipar, por medio de la interpretación de las leyes penales, la falta de claridad que pueda subsistir respecto de su ámbito de aplicación. Este deber se denomina por el tribunal alemán "mandato de precisión" (Präzisierungsgebot) y tendría especial importancia en aquellos tipos que el legislador, en el marco de lo que le permite la Constitución, ha concebido de manera relativamente amplia e imprecisa, a través del empleo de cláusulas generales. ${ }^{71}$ De esta manera, el principio nulla poena sine lege no solo impediría a los jueces aplicar analógicamente tipos penales, o fundar una condena otorgando valor a la costumbre, sino que, además, los obligaría a colaborar con el Parlamento en la tarea de concretizar los presupuestos de la punibilidad.

La sentencia recién aludida es cuestionable. Es cierto que, de acuerdo con los avances experimentados por la metodología jurídica, la aplicación de la ley ya no se puede entender como un mero proceso de subsunción lógica o mecánica, sino como una labor de interpretación y de concreción de normas jurídicas generales. ${ }^{72}$ Sin embargo, una cosa es reconocer que la aplicación de una ley penal a una constelación fáctica determinada obliga a esclarecer su sentido, y precisar sus elementos típicos abstracto-generales, y otra cuestión muy distinta es que los tribunales sean corresponsables de la taxatividad de la ley. No se puede confundir la interpretación de las normas de sanción penal, que tiene que ser asumida por los aplicadores del Derecho, con la fijación de sus presupuestos, tarea que solo compete

\footnotetext{
${ }^{67}$ Así SCHÜNEMANN (1978), p. 32.

${ }^{68}$ DUTTGE (2001), p. 182; LAGODNY (1996), p. 398; en un sentido similar FREUND (2013), p. 43.

${ }^{69}$ Véase ALEXY (1986), pp. 92 y s.; de acuerdo con él LAGODNY (1996), p. 398.

${ }^{70}$ En este sentido, entre otros, KRAHL (1986), pp. 342 y s.; KUHLEN (2007), pp. 102 y ss.

${ }^{71}$ BVerfGE 126, 170, 198; apoyando esta decisión KIRSCH (2014), pp. 158 y ss. con ulteriores referencias.

${ }^{72}$ Sobre estos avances, ilustrativo ENGISCH (2010), pp. 189 y ss.
} 


\section{Polít. Crim. Vol. 16, № 31 (Junio 2021), Art. 7, pp. 164-196. [http://politcrim.com/wp-content/uploads/2021/05/Vol16N31A7.pdf]}

al legislador. ${ }^{73}$ Cuando se pone en manos de los tribunales la tarea de contribuir a la determinación de los presupuestos típicos, se está desconociendo, precisamente, lo que las constituciones alemana y chilena exigen para la legitimación formal de la pena, a saber: que la conducta punible esté fijada por la ley, y no por los jueces.

1.2.6. Toma de postura sobre las exigencias que impone el mandato de determinación al legislador penal

Para desarrollar una toma de postura respecto de las exigencias que impone el mandato de determinación al legislador, es necesario tener presente la distinción entre normas de conducta y normas de sanción penal. ${ }^{74}$ Estas últimas constituyen reglas que ordenan declarar la culpabilidad e imponer una determinada pena como reacción frente al quebrantamiento de una norma de conducta. ${ }^{75}$ Las normas de sanción están dirigidas al juez, indicándole bajo qué presupuestos, formulados en términos abstracto-generales, tiene que sancionar penalmente un comportamiento contrario a deber. Entre estos presupuestos se cuentan, por ejemplo, una acción u omisión dolosa o imprudente, el acaecimiento de un resultado imputable objetivamente a la conducta, la ausencia de una causa de justificación, la capacidad de decidirse por el Derecho, etc. Así, por ejemplo, el art. 391 n ${ }^{\circ} 2$ del CP, en relación con los preceptos correspondientes de la parte general del mismo cuerpo de leyes, constituye una norma de sanción, que obliga a castigar con pena privativa de libertad a quien genere, por medio de una conducta dolosa, un riesgo jurídicamente desaprobado para la vida de otro, y cause su muerte de un modo imputable objetivamente, siempre que no haya actuado en legítima defensa, tenga capacidad para responder penalmente, etc. Ahora bien, las normas de sanción penal no contienen normas de conducta, esto es, deberes en forma de prohibiciones o mandatos que le indiquen al sujeto cómo actuar en una situación concreta para evitar o disminuir riesgos para bienes jurídicos. Estas últimas normas se hallan en el denominado "orden primario de comportamiento" u "orden de conducta", sobre el cual se erigen las normas de sanción, cuya finalidad inmediata no es la conservación de bienes jurídicos, sino la confirmación de la vigencia del Derecho quebrantado. ${ }^{76}$

Ahora bien, es necesario tener presente que no es tarea del legislador penal establecer normas de conducta para todas las situaciones imaginables posibles; estas son demasiado variadas, mutables y complejas como para que aquel pueda fijar con detalle los múltiples comportamientos que pueden ser necesarios para conservar bienes jurídicos de terceros. ${ }^{77}$ Ejemplo: el Poder Legislativo no está en condiciones de aprobar leyes penales que incluyan todos los deberes de cuidado que los empleadores del sector de la minería, de la construcción o de la industria tienen que cumplir, para así evitar accidentes laborales que causen muertes o lesiones. Tampoco puede crear delitos en los cuales se establezca el conjunto de deberes de cuidado que los médicos pertenecientes a diferentes especialidades han de acatar, con la finalidad de no crear peligros desaprobados en perjuicio de la vida o salud de sus pacientes.

\footnotetext{
${ }^{73}$ Confróntese NAVARRO (2010), p. 69.

${ }^{74}$ Sobre la diferenciación entre normas de conducta y normas de sanción véase, por todos, FREUND y ROSTALSKI (2019), § 1 nm. 49 y ss.; FRISCH (1983), pp. 59 y s., 77, 348, 356 y s., 502 y ss.

${ }^{75}$ Véase FREUND y ROSTALSKI (2019), § $1 \mathrm{~nm} .69$.

${ }^{76}$ En este sentido FRISCH (1983), p. 48; de acuerdo con él FREUND y ROSTALSKI (2019), § $1 \mathrm{~nm} .50$.

${ }^{77}$ Así lo destaca, correctamente, FREUND (2013), p. 38; en un sentido similar FREUND y ROSTALSKI (2016), p. 445.
} 
Pero no se trata solo de que sea una ilusión suponer que el legislador penal pueda crear programas exhaustivos de eliminación o minimización de riesgos como los recién descritos; tampoco el legislador civil, administrativo, laboral, etc. está en condiciones de hacerlo. Por ello, con mucha frecuencia, los deberes de comportamiento que rigen en una situación concreta, y que permiten proteger eficazmente la vida o salud de terceros, no se pueden fijar por medio de normas extrapenales, sino solo extrajurídicas (por ejemplo, las contenidas en la lex artis médica o aquellas que dicta el Instituto Nacional de Normalización). En otras ocasiones, ni siquiera existen normas extrajurídicas que indiquen cómo eliminar o disminuir peligros en una determinada situación, y le corresponde al propio sujeto concebir los deberes de cuidado que rigen a su respecto. ${ }^{78}$

Pues bien, si el legislador penal no está en condiciones de establecer normas de conducta detalladas para proteger bienes jurídicos, y el Derecho Constitucional no puede obligarlo a cumplir lo imposible, sería incorrecto interpretar la expresión "conducta", que aparece en el inc. final del art. 19 n'3 de nuestra Constitución Política, como "comportamiento exigible en una situación determinada”. ¿Cómo debería entonces interpretarse dicha expresión?

La respuesta a esta pregunta supone tener claridad acerca de la finalidad del mandato de determinación en un Estado de Derecho, y de la labor originaria del legislador penal en el marco de esta exigencia constitucional. Como ya se indicó, el mandato de determinación persigue la necesaria separación de competencias estatales respecto de las tareas de creación y de aplicación de tipos delictivos. La facultad de declarar la culpabilidad del autor e imponerle una sanción criminal, es decir, de aplicar una norma de sanción penal en un caso determinado, es privativa de los tribunales penales; para intervenir, requieren de un fundamento expreso habilitante en forma de tipo legal. El mecanismo que tiene el Poder Legislativo para conceder tal fundamento habilitante consiste en establecer en una ley, mediante características abstracto-generales, la clase o género de infracciones a normas de conducta que deben ser castigadas por los tribunales, concurriendo los restantes presupuestos de la sanción. ${ }^{79}$

Por consiguiente, la expresión "conducta", a que alude el inc. final del art. 19 n³ de la Constitución, debe entenderse como una "clase o género de conductas contrarias a deber". Esta exigencia de determinación se cumple claramente cuando, por ejemplo, la ley indica en el art. 416 del Código Penal que debe castigarse una clase de conductas consistentes en expresiones proferidas o acciones ejecutadas "en deshonra, descrédito o menosprecio de otra persona"; o cuando el art. 366 ter (en relación con los arts. 365 bis, 366 y 366 bis) del mismo Código ordena sancionar un género de comportamientos en forma de actos de "significación sexual y de relevancia realizado[s] mediante contacto corporal con la víctima (...)”, o, finalmente, cuando el art. $494 \mathrm{n}^{\circ} 16$ del cuerpo legal referido dispone que tiene que castigarse

\footnotetext{
${ }^{78}$ Lo que es destacado acertadamente por PUPPE (2017), nm. 155. En este orden de ideas, piénsese, por ejemplo, en los deberes de cuidado que un adulto a cargo de un bebé tiene que concebir por sí mismo, y cumplir a continuación, para resguardar la vida y salud de la criatura.

${ }^{79}$ Así, FREUND (2013), p. 39. Confróntese también HERZBERG (2005), pp. 49 y ss., para quien el mandato de taxatividad solo exige al legislador fijar la punibilidad de un determinado "tipo de acción". Véase asimismo OSSANDÓN (2009), p. 505 (el mandato de determinación exige delimitar "al menos genéricamente" el desvalor de comportamiento).
} 


\section{Polít. Crim. Vol. 16, № 31 (Junio 2021), Art. 7, pp. 164-196. [http://politcrim.com/wp-content/uploads/2021/05/Vol16N31A7.pdf]}

una clase de conductas que consisten en impedir "a otro con violencia hacer lo que la ley no prohíbe", o compelerle a "ejecutar lo que no quiera".

A través de la descripción legal de la clase o género de infracciones a normas de conducta que tienen que ser castigadas, el tenor literal de la norma de sanción fija los límites externos de aquello que puede ser abarcado por ella. ${ }^{80}$ Luego, las acciones u omisiones que no puedan subsumirse en dicha clase o género, descrito en el tenor literal, no podrán ser sancionadas por el juez, aun cuando su castigo se corresponda con la finalidad de la norma de sanción, puesto que la analogía nunca puede ser fuente de delitos. ${ }^{81}$

Ahora bien, de acuerdo con el inc. final del art. 19 nº 3 de la Constitución Política, no basta con que la norma legal de sanción describa la clase o género de comportamientos que tienen que ser castigados, sino que además, es necesario que tal descripción sea expresa. Esto obliga al legislador a establecer con precisión suficiente la clase o género de infracciones a normas de conducta que tiene que ser sancionada a través de una pena. ${ }^{82}$ La descripción de los comportamientos contrarios a deber será suficientemente precisa cuando la ley penal permita reconocer el bien jurídico que protegen las normas de conducta cuya vigencia ha de ser estabilizada por medio de la pena ${ }^{83}$ Ese bien jurídico se podrá inferir frecuentemente del resultado lesivo al que alude la ley penal, de la ubicación sistemática de esta, o de la naturaleza de los peligros que generan los comportamientos contrarios a Derecho castigados penalmente.

La importancia de que la ley penal permita identificar el bien jurídico de las normas de conducta a las que se refiere, para que se dé por cumplido el mandato de determinación, obedece a la siguiente razón: la finalidad de las normas de sanción penal no es confirmar la vigencia de normas de comportamiento cualesquiera, sino solo la de aquellas prohibiciones

\footnotetext{
${ }^{80}$ Confróntese FREUND (2013), p. 39.

${ }^{81}$ Sobre la prohibición de analogía in malam partem en Derecho Penal véase MURMANN (2017), $§ 10 \mathrm{~nm} .5$ y s.

${ }^{82}$ Confróntese FREUND y ROSTALSKI (2016), pp. 444 y s. Destaca el aspecto de la "precisión" de la ley en el contexto del mandato de determinación, entre otras, las sentencias del Tribunal Constitucional: roles 2773 (2817, 2849 y 2859)-15-INA, acumulados, 28 enero de 2016, considerandos $10^{\circ}$ y $14^{\circ}$; rol 3329-17-INA, 23 agosto de 2018, considerando $19^{\circ}$; rol 5304-18-INA, 27 de junio de 2019, considerando $14^{\circ}$.

${ }^{83}$ En este sentido, correctamente, FREUND (2015), pp. 584 y ss., 596; en una línea similar OSSANDÓN (2009), p. 504, así como RANSIEK (2008), p. 176. La afirmación de que una norma de sanción es determinada cuando permite reconocer el bien jurídico que protegen las normas de conducta cuya vigencia debe ser estabilizada por medio de la pena, no implica renunciar a la exigencia de que la ley contemple un "verbo rector". Este no es sino la descripción de la clase o género de infracciones a normas de conducta que han de ser castigadas. Por otra parte, un tipo penal que aludiera a una clase o género extremadamente amplio de comportamientos infractores de deber, pero que permitiera reconocer el bien jurídico de las normas de conducta cuya vigencia tiene que ser estabilizada, podría —a juicio de van Weezel - arrojar dudas sobre su constitucionalidad. Este autor aporta el siguiente ejemplo ficticio: "el que afecte la propiedad ajena será castigado con la pena de...". (VAN WEEZEL (2011), p. 96). El problema aquí, sin embargo, no es de falta de taxatividad de los tipos penales, sino de contravención de la garantía de la igualdad ante la ley (art. $19 \mathrm{n}^{\circ} 2$ de la Constitución Política). Y es que un delito semejante abordaría de la misma forma supuestos que presentan un contenido de injusto muy diferente (afectación de la propiedad ajena ejerciendo violencia o no ejerciéndola, afectación de la propiedad ajena respecto de cosas de distinto valor, etc.) y que deberían tener penas diferenciadas. Es decir, el legislador penal trataría de igual forma conductas que merecen un trato distinto, lo que implicaría un quiebre de la igualdad ante la ley.
} 
o mandatos legítimos. ${ }^{84}$ En tanto restricciones a la libertad general de actuación de los ciudadanos, las normas de conducta tienen que satisfacer los requisitos impuestos por la Carta Fundamental a la afectación de derechos constitucionales. Esto implica, especialmente, que deben perseguir un fin legítimo, a saber: conservar un bien jurídico concreto. Si no es posible identificar un bien jurídico determinado que justifique la afectación a la libertad representada por la clase o género de normas de conducta cuya vigencia ha de ser estabilizada, tampoco se estará frente a una norma de sanción que se pueda legitimar. ${ }^{85}$ Y es que las normas de sanción no pueden servir para eliminar el peligro de un daño a la vigencia de prohibiciones o mandatos que limiten arbitrariamente la libertad de las personas, al no proteger un bien jurídico determinado. Expresado de otra forma: en un Estado de Derecho, la pena no puede emplearse para estabilizar la vigencia de normas de conducta inconstitucionales.

La interpretación que aquí se propone de la locución "expresamente descrita", empleada por el inc. final del art. 19 n 3 de la Carta Fundamental, permitiría explicar por qué el delito de incumplimiento de deberes militares, contemplado en el art. 299 n³ del Código de Justicia Militar, no satisface el mandato de determinación. La formulación típica (“el que (...) deje de cumplir sus deberes militares") impide reconocer cuál o cuáles son los bienes jurídicos que buscan proteger las normas de conducta cuya vigencia tiene que ser reforzada por medio de la pena. Luego, este delito se refiere al quebrantamiento de normas de conducta que no se pueden legitimar constitucionalmente. Un quebrantamiento semejante no está en condiciones de justificar la grave afectación de derechos fundamentales que significa la declaración de culpabilidad del autor y la imposición de una pena a su respecto. Por otra parte, la circunstancia de que en Chile los miembros de las fuerzas armadas estén, desde el inicio de su formación, familiarizados con las prohibiciones y mandatos (con los "deberes militares") que han de observar en el ejercicio de sus funciones, no puede ser un argumento para afirmar la constitucionalidad de este delito ${ }^{86}$. El conocimiento de deberes jurídicos que indican cómo actuar en situaciones concretas puede tener relevancia en el plano de la conciencia del injusto, pero no permite fundar la taxatividad de una norma de sanción penal. Habiendo aclarado cuál es la finalidad del mandato de determinación, y qué exigencias impone al legislador penal chileno, corresponde ahora exponer y revisar críticamente los argumentos de los autores que plantean la inconstitucionalidad de los delitos imprudentes de homicidio y lesiones.

\section{Revisión y análisis crítico de la teoría de la indeterminación de los delitos imprudentes de homicidio y lesiones}

Los autores que han encabezado el cuestionamiento a la taxatividad de los delitos imprudentes de homicidio y lesiones han sido Gunnar Duttge y Roland Schmitz. Fundamentalmente en sus contribuciones al tomo primero del Münchener Kommentar zum Strafgesetzbuch, ${ }^{87}$ pero también en otras obras, han construido una "teoría de la indeterminación" de los ilícitos mencionados. Si bien sus planteamientos críticos se refieren al conjunto de los delitos imprudentes previstos en el Código Penal alemán, los autores

\footnotetext{
${ }^{84}$ Así, TIMM (2012), p. 48.

${ }^{85}$ FREUND (2015), p. 585.

${ }^{86}$ Sin embargo, este ha sido el argumento de nuestro Tribunal Constitucional para declarar, que el delito de incumplimiento de deberes militares se ajusta al mandato de taxatividad (rol 559-2006, 7 de junio de 2007 , considerando $10^{\circ}$ ).

${ }^{87}$ JOECKS y MIEBACH (2017), passim.
} 


\section{Polít. Crim. Vol. 16, № 31 (Junio 2021), Art. 7, pp. 164-196. [http://politcrim.com/wp-content/uploads/2021/05/Vol16N31A7.pdf]}

señalados prestan una especial atención a la supuesta incompatibilidad de los delitos previstos en los $\S \S 222$ y 229 de dicho cuerpo legal con la exigencia de taxatividad ${ }^{88} \mathrm{El} \S 222$ castiga a quien ocasione "la muerte de una persona por imprudencia", mientras que el $\S 229$ sanciona a "quien por imprudencia cause la lesión corporal" de otro. En las líneas siguientes se expondrán los principales argumentos de la teoría de la indeterminación.

\subsection{Las razones para afirmar la indeterminación de los delitos imprudentes de homicidio y lesiones}

\subsubsection{La postura de Duttge}

A juicio de Duttge, el cumplimiento del mandato de determinación supondría la elaboración de leyes penales que proporcionen al aplicador del derecho, pero sobre todo al ciudadano, la necesaria "seguridad de expectativas", a partir de la cual pueda distinguir claramente entre los comportamientos socialmente adecuados, por una parte, y los penalmente relevantes y amenazados con pena, por otra ${ }^{89}$ En materia de delitos culposos, el legislador penal no se habría preocupado de describir los criterios que concretizan el comportamiento imprudente..$^{90}$ Esta falta de regulación del derecho positivo no solo se referiría a las características detalladas que debería revestir una actuación u omisión culposa para ser castigada, sino también a criterios generales que permitan delinear el comportamiento negligente; así, el término "imprudencia" que emplean los $\$ \S 222$ y 229 del Código Penal alemán no está definido legalmente. ${ }^{91}$ Por otra parte, del $\S 15$ de dicho Código ${ }^{92}$ únicamente se puede inferir que la negligencia se sitúa en un mismo nivel categorial que el dolo, y que posee un menor peso criminal que este. ${ }^{93}$ En virtud de ello, Duttge sostiene que este precepto estaría muy lejos de satisfacer las exigencias de una regulación legal de los presupuestos de la punibilidad. ${ }^{94}$ De este modo, el contenido del comportamiento típico del homicidio y de las lesiones imprudentes quedaría entregada por completo al trabajo de concreción desplegado por la jurisprudencia y la doctrina, en circunstancias que el art. 103, párrafo 2, de la Constitución alemana obliga a una determinación legal, y no solo jurisprudencial o doctrinaria del ámbito de lo punible. ${ }^{95}$

Para Duttge, en los tipos imprudentes de homicidio y lesiones no existiría certeza en torno a qué constelaciones fácticas quedan abarcadas por ellos; por consiguiente, sobre los

\footnotetext{
${ }^{88}$ Esta especial preocupación por los delitos imprudentes de homicidio y lesiones probablemente se explica porque, a diferencia de estos, los delitos culposos de mera actividad, previstos en el Código Penal alemán, aluden a una clase o género muy concreta de infracciones a normas de conducta que han de ser castigadas (por ejemplo, el párr. $1^{\circ}$ del $\S 163$ StGB castiga, entre otros, a quien por imprudencia declare en falso ante un tribunal u otra dependencia competente para prestar juramento, mientras que el párr. $2^{\circ}$ del $\S 316$ StGB sanciona a quien por imprudencia conduzca un vehículo pese a no estar en condiciones de hacerlo a causa de ingerir bebidas alcohólicas).

${ }^{89}$ DUTTGE (2017), nm. 35.

${ }^{90}$ DUTGGE (2014), p. 266.

${ }^{91}$ DUTTGE (2017), nm. 33.

${ }^{92} \mathrm{El} \S 15$ StGB dispone: "La acción dolosa sólo es punible cuando por ley no está amenazada expresamente con pena la acción culposa".

93 DUTTGE (2003), p. 26.

${ }^{94}$ Confróntese DUTGGE (2014), p. 266.

${ }^{95}$ DUTTGE (2017), nm. 33 y s.
} 
ciudadanos pendería siempre "la espada de Damocles del Derecho penal", sin que puedan estos quedar a salvo de la sanción criminal a través de la evitación de determinadas conductas. ${ }^{96}$ En una "sociedad de riesgo", en la cual los comportamientos peligrosos nunca se pueden evitar por completo, el principio básico del neminem laedere perdería su eficacia si no es posible reconocer en los tipos referidos una alternativa de conducta prevista legalmente; si no hay normas de conducta que permitan evitar la lesión a la vida o la salud, nadie puede ser motivado a la evitación del daño. ${ }^{97}$

Las objeciones relativas a la constitucionalidad de los delitos imprudentes de homicidio y lesiones no disminuirían por la circunstancia de contemplar el ordenamiento jurídico cláusulas generales, que también carecerían de determinación (por ejemplo: el carácter de "reprochable" de la acción, que exige el tipo de coacciones previsto en el $\S 240 \mathrm{StGB}$ ), ni tampoco por las consecuencias que tendría una "petrificación" o "congelamiento" de la legislación, derivada de una regulación más detallada de la negligencia. ${ }^{98}$

Pese a señalar Duttge que, en el ámbito de la imprudencia, el legislador infringe su deber de establecer el límite entre lo punible y lo no punible, y no obstante declarar de manera expresa que actualmente la regulación legal del homicidio y de las lesiones culposos contradice de manera clara el mandato de determinación, ${ }^{99}$ el mismo autor indica que lo anterior no conlleva la invalidez de los respectivos tipos, en la medida que estos puedan ser interpretados conforme a la Constitución, es decir, restrictivamente. ${ }^{100}$ Dicha interpretación sería posible vinculándola con la "esencia de la imprudencia", que correspondería a lo que Duttge denomina "momento motivador" (Veranlassungsmoment). De este modo, para estar en presencia de un comportamiento imprudente sería decisiva la evitabilidad concreta del resultado dañoso, lo que presupondría una reconocibilidad individual del curso causal lesivo en la situación respectiva, basada en un motivo fundado en la realidad exterior. ${ }^{101}$

\subsubsection{El planteamiento de Schmitz}

A diferencia de Duttge, quien sostiene que la incompatibilidad de los delitos imprudentes de homicidio y lesiones con el mandato de determinación podría salvarse a través de una interpretación de acuerdo con la Constitución, Schmitz afirma sin matizaciones tal incompatibilidad. Según este último autor, el legislador incumple el mandato de determinación cuando, no obstante declarar punibles determinadas formas de comportamiento, renuncia a una regulación de los presupuestos de su sanción. ${ }^{102}$ Esto ocurriría tratándose de los delitos culposos, en los cuales la ley no establece qué debe entenderse por "imprudencia", y en donde el conjunto de los presupuestos de la punibilidad

\footnotetext{
${ }^{96}$ DUTTGE (2017), nm. 37.

${ }^{97}$ DUTGGE (2014), p. 266.

${ }^{98}$ DUTTGE (2017), nm. 34.

${ }^{99}$ DUTTGE (2001), pp. 205 y s.

${ }^{100}$ DUTTGE (2001), p. 206; DUTGGE (2014), p. 270.

101 Véase DUTTGE (2001), p. 493. Crítico respecto de la concepción de Duttge sobre el desvalor de conducta imprudente ROXIN (2006), § 24 nm. 47 y ss.

102 SCHMITZ (2017), nm. 56.
} 


\section{Polít. Crim. Vol. 16, № 31 (Junio 2021), Art. 7, pp. 164-196. [http://politcrim.com/wp-content/uploads/2021/05/Vol16N31A7.pdf]}

ha sido desarrollado por la jurisprudencia y la doctrina, sin que el legislador los haya refrendado. ${ }^{103}$

Por otra parte, de la expresión "cuidado necesario en el tráfico", contenida en el párrafo 2 del $\S 276$ del Código Civil alemán, y frecuentemente invocada para concretar el desvalor de comportamiento de los homicidios y lesiones imprudentes, no es posible inferir cuáles son las conductas que hay que adoptar u omitir para evitar daños a la vida o a la salud; tal expresión constituye un concepto jurídico indeterminado, cuyos contornos la ley no precisa y que tienen que ser concretizado por los tribunales. ${ }^{104}$ Además, si el art. 103 párrafo 2 de la Constitución alemana exige que el Poder legislativo (y no la judicatura, ni tampoco la doctrina) fije los presupuestos de la sanción penal, solo se podría renunciar a una descripción legal detallada de lo punible cuando esto fuera superfluo, porque tales presupuestos ya son evidentemente cognoscibles, o los ciudadanos los pueden reconocer con cierta facilidad..$^{105}$ El que este no sea el caso respecto de los delitos imprudentes de homicidio y lesiones quedaría demostrado por la larga e intensa discusión dogmática acerca de su estructura y alcance, por ejemplo, en relación a si debe admitirse una culpa inconsciente junto a una consciente. ${ }^{106}$

Para Schmitz, el mandato de determinación facilitaría al ciudadano la tarea de reconocer ex ante el ámbito de la conducta punible y, de este modo, orientar su comportamiento. ${ }^{107}$ Por eso, para un Derecho penal que pretenda no solo sancionar arbitrariamente al individuo, sino cumplir una función de dirección de conductas, la observancia del principio de determinación resultaría decisiva. ${ }^{108}$ A juicio de este autor, no solo las normas de sanción, sino también las de conducta tendrían que estar suficientemente precisadas por la ley; solo así el ciudadano puede tener claridad acerca del límite entre el comportamiento permitido y el penalmente prohibido. ${ }^{109}$

Finalmente, a juicio de Schmitz, una falta de regulación precisa de los delitos imprudentes de homicidio y lesiones no se puede justificar con el argumento de que una descripción legal más detallada de estos ilícitos no sería posible. Tal posibilidad quedaría demostrada, verbigracia, con el § 6 del Código Penal austríaco o el párrafo 3 del $§ 12$ del Código Penal suizo, que establecen sendos conceptos de culpa. ${ }^{110}$

\footnotetext{
${ }^{103}$ SCHMITZ (2017), nm. 58; ver también SCHMITZ (2010), pp. 182 y 189.

${ }^{104}$ SCHMITZ (2010), p. 196.

${ }^{105}$ SCHMITZ (2010), pp. 190 y s.

${ }^{106}$ SCHMITZ (2010), p. 191.

${ }^{107}$ SCHMITZ (2010), pp. 183 y s.

${ }^{108}$ SCHMITZ (2010), p. 184.

${ }^{109}$ SCHMITZ (2010), p. 185.

${ }^{110}$ SCHMITZ (2017), nm. 59.
} 


\subsection{Críticas a la teoría de la indeterminación de los delitos imprudentes de homicidio y lesiones}

2.2.1. La aparente insuficiencia de los tipos imprudentes de homicidio y lesiones para orientar la conducta

De acuerdo con la teoría de la indeterminación, los delitos imprudentes de homicidio y lesiones serían inconstitucionales puesto que no precisarían suficientemente las normas de conducta que tienen que acatarse en el caso concreto para estar a salvo de responsabilidad penal. Así, estos delitos no permitirían distinguir entre los comportamientos socialmente adecuados, por una parte, y los comportamientos prohibidos y sancionados con pena, por otra. Sobre los ciudadanos que realizan actividades riesgosas para la vida o salud se cerniría permanentemente la amenaza penal, sin que supieran qué medidas adoptar para evitar el castigo.

Las argumentaciones arriba expuestas se basan probablemente en una confusión. Como ya se explicó, por medio de las normas de sanción penal el legislador no le indica al ciudadano qué comportamientos tiene que ejecutar u omitir para evitar, en situaciones particulares, peligros para bienes jurídicos. Las normas de conducta que permiten en tales situaciones la protección de la vida y salud, y que sirven de delimitación entre los riesgos tolerados y desaprobados respecto de esos bienes, se encuentran en el orden primario de comportamiento, no en los tipos de homicidio o lesiones imprudentes de los $\$ \S 222$ y 229 StGB. En la medida que el sujeto observe las reglas del orden primario de conducta, puede confiar legítimamente en que su comportamiento no será desaprobado por el Derecho y, por consiguiente, no será penado.

Los tipos previstos en las normas recién señaladas no tienen por objeto facilitar la distinción entre lo prohibido y lo jurídicamente permitido respecto de los bienes vida y salud, sino (tan solo) diferenciar entre las conductas merecedoras de pena y aquellas simplemente prohibidas por el orden primario, ${ }^{111}$ otorgando un fundamento habilitante para que el juez sancione las primeras. Para ello, los tipos imprudentes de homicidio y lesiones establecen legalmente qué clase o género de infracciones a normas de conducta son punibles, reuniéndose otros presupuestos adicionales. Tal clase o género está suficientemente determinado y corresponde, naturalmente, a infracciones a deberes jurídicos que protejan la vida $(\$ 222$ StGB) y la salud ( $\$ 229$ StGB), los que tienen que ser penados en la medida que se haya verificado un resultado imputable objetivamente, no concurra una causa de justificación, el autor haya sido capaz de decidirse por el Derecho, etc.

2.2.2. La supuesta incapacidad de los tipos imprudentes de homicidio y lesiones para proteger bienes jurídicos

Tampoco es correcta la afirmación de que, en una "sociedad de riesgo", el principio del neminem laedere perdería su eficacia si los tipos imprudentes de homicidio y lesiones no contemplaran alternativas de comportamiento que permitan evitar los daños a la vida o la salud. Una adecuada protección de estos bienes jurídicos no se logra directamente a través

${ }^{111}$ La única advertencia que los tipos imprudentes de homicidio y lesiones están en condiciones de hacer a los ciudadanos es una de carácter general, y es la siguiente: "si causas la muerte o lesiones a otro de manera jurídicamente desaprobada, serás castigado” (confróntese FREUND y ROSTALSKI (2015), p. 13). 


\section{Polít. Crim. Vol. 16, № 31 (Junio 2021), Art. 7, pp. 164-196. [http://politcrim.com/wp-content/uploads/2021/05/Vol16N31A7.pdf]}

de normas de sanción, ${ }^{112}$ sino por medio de un sistema diferenciado de normas de conducta. La fijación mediante leyes (sean estas penales o extrapenales) de lo que tiene que hacerse u omitirse en situaciones específicas para no dañar la vida o la salud de otros, es una tarea irrealizable ${ }^{113} \mathrm{y}$, además, haría fracasar (a causa de la rigidez característica de las disposiciones legales) la función legítima de las normas de conducta, a saber: prevenir en ámbitos situacionales muy concretos comportamientos peligrosos para bienes jurídicos. ${ }^{114}$

Para lograr una efectiva prevención de conductas riesgosas, una descripción general como la contenida en el párrafo $3^{\circ}$ del $\S 12$ del Código Penal suizo ("la imprudencia es contraria a deber si el autor no ha observado el cuidado al que está obligado según las circunstancias del suceso y sus relaciones personales"), no resulta útil. Tampoco una comprensión del desvalor de conducta imprudente que ponga su acento en un "momento motivador", como lo hace Duttge, permite fijar alternativas de comportamiento precisas que logren disminuir los riesgos para bienes jurídicos.

\subsubsection{La aparente falta de certeza en torno a las constelaciones fácticas abarcadas}

También resulta infundada la aseveración de los partidarios de la teoría de la indeterminación que postula que, en los tipos de homicidio y lesiones imprudentes, no existiría certeza en torno a qué constelaciones fácticas quedan abarcadas por ellos. En efecto, es una ilusión pensar que el legislador penal pueda describir todos y cada uno de los innumerables casos que cumplen los presupuestos de dichos tipos, de tal modo que el tribunal solo necesite aplicar estos en forma mecánica al supuesto que está juzgando. ${ }^{115}$ Sin embargo, los $§ \S 222$ y 229 del StGB contienen normas suficientemente claras que le ordenan al juez declarar la culpabilidad del autor e imponerle una pena en caso de que se reúnan ciertas condiciones previstas legalmente. ${ }^{116}$ Ahora bien, el que estas condiciones se cumplan en un determinado caso es algo que tiene que fundamentar el tribunal penal, para lo cual no basta que reproduzca los $\S 222$ o 229 StGB, o deduzca la tipicidad del hecho únicamente a partir de los conceptos abstracto-generales previstos en estas normas. Por el contrario, el juez tiene que elaborar un razonamiento suficiente para demostrar que el autor ha ejecutado u omitido un comportamiento quebrantando un deber jurídico específico, y que aquel pertenece a la clase o género de infracciones a normas de conducta a las que el respectivo tipo penal alude. ${ }^{117}$

\footnotetext{
${ }^{112}$ Para el bien jurídico afectado en el caso concreto, la aplicación de una norma de sanción penal siempre llega demasiado tarde: la pena no hará volver a la vida a la víctima de un homicidio imprudente, ni restablecerá la salud del ofendido por el delito de lesiones culposas. La sanción penal solo puede proteger aquello que todavía puede ser protegido luego del delito, a saber: la vigencia de las normas de conducta que el autor del delito ha puesto en tela de juicio con su hecho. Véase CONTRERAS (2012), p. 6, con ulteriores referencias.

${ }^{113}$ Nuestro Tribunal Constitucional ha destacado, en este sentido, que "es imposible prever todos los deberes de cuidado en una norma legal" (rol 2716-14-INA, 10 de septiembre de 2015, considerando $35^{\circ}$ ).

${ }^{114}$ Confróntese FREUND y ROSTALSKI (2015), p. 13.

${ }^{115}$ Nuestro Tribunal Constitucional ha señalado, en este orden de ideas, que: “...en los delitos culposos hay una relativa indeterminación, pues es imposible describir con mayor exactitud en la ley todos los comportamientos imprudentes..." (rol 2716-14-INA, 10 de septiembre de 2015, considerando $35^{\circ}$ ).

${ }_{116}$ Confróntese en lo que sigue FREUND (2007), p. 64 y s.

${ }^{117}$ Como el legislador penal no puede aportar todo lo necesario para concretizar el Derecho en cada uno de los casos que se pueden presentar en la vida social, se requiere una actuación conjunta en división del trabajo entre legislador penal y juez: el primero, fijando la clase o género de infracciones a normas de conducta que tienen que ser sancionadas (en la medida que se reúnan los restantes presupuestos típicos) y el segundo,
} 
Aquí es fundamental que el órgano jurisdiccional identifique el deber jurídico concreto que inequívocamente el autor tenía que cumplir. En el caso de que no sea claro si el Derecho obligaba al autor a comportarse de una manera distinta a la que lo hizo, no será legítimo declarar su culpabilidad e imponerle una pena. La aplicación de los tipos penales persigue la confirmación de una determinada norma de conducta quebrantada, y solo puede confirmarse aquella norma que inequívocamente regía en la situación en que se encontraba el autor. ${ }^{118}$ Por ello, si el comportamiento del sujeto es uno que se sitúa, todavía, dentro del ámbito de las acciones $u$ omisiones que pueden ser vistas como razonables frente al mundo de los bienes jurídicos, su castigo constituye algo enteramente disfuncional desde el punto de vista de los fines de la pena.

La labor de fundamentación recién descrita, necesaria para legitimar en un caso concreto la declaración de culpabilidad del autor y la imposición de una pena a su respecto, no la puede llevar a cabo el legislador; antes bien, se trata de una tarea propia y exclusiva de los tribunales. La necesidad de fundar la condena puede verse como la consecuencia forzosa de que aquello que está regulado en los $\S \S 222$ y 229 StGB nunca es la decisión del caso concreto; tal decisión solo la puede adoptar un juez. ${ }^{119}$ Sin embargo, ello en ningún caso significa que en los tipos de homicidio y lesiones imprudentes no exista certeza en torno a qué constelaciones fácticas quedan abarcadas.

\subsection{4. ¿Interpretación conforme a la Constitución?}

Por otra parte, la postura de Duttge consistente en que los tipos penales imprudentes infringen abiertamente el mandato de determinación, no obstante lo cual tendría que favorecerse una interpretación de ellos conforme a la Constitución, no parece ser sostenible. ${ }^{120}$ En efecto, de acuerdo con esta modalidad de interpretación, en caso de existir al menos dos exégesis posibles de una norma legal, esto es, una que permite estimarla constitucional, y otra que lleva a afirmar su inconstitucionalidad, tiene que preferirse la primera de ellas. ${ }^{121} \mathrm{La}$ interpretación conforme a la Constitución de un precepto legal presupone, por tanto, al menos una exégesis de este que lleve a afirmar su constitucionalidad. Pero precisamente esto es lo que niega Duttge, cuando afirma, antes de plantear esa forma de interpretación como mecanismo para "salvar" la constitucionalidad de los delitos imprudentes de homicidio y lesiones, que estos contradicen abiertamente el mandato de determinación.

Además, cualquier interpretación conforme a la Constitución implica, necesariamente, una actividad de la jurisprudencia o de la doctrina dirigida a aclarar el sentido de una norma legal. Sin embargo, el mismo autor cuestiona que sean los tribunales o la ciencia penal, y no la ley,

fundamentando por qué en el caso concreto el autor ha realizado u omitido una conducta contraria a deber perteneciente a esa clase o género (y por qué se satisfacen las restantes condiciones).

118 Confróntese FREUND (2019), p. 12; FREUND (2013), p. 40.

${ }^{119}$ En este sentido FREUND (2007), p. 64.

${ }^{120}$ Críticos también, en este sentido, HERZBERG (2015), pp. 423 y ss.; KIRSCH (2014), p. 165 y ss. A favor de la interpretación conforme a la Constitución como mecanismo para solucionar problemas de certeza en la descripción de las normas de sanción penales, FERNÁNDEZ (2017), pp. 653 y ss. (bajo la condición de que la ley penal contenga un "mínimo de precisión y claridad").

${ }^{121}$ Así KUHLEN (2006), p. 1. Sobre la interpretación conforme a la Constitución, véanse, entre otras, las sentencias del Tribunal Constitucional chileno, rol 2800-15-INC, 8 de marzo de 2016, considerando $4^{\mathrm{o}}$; rol 1584-09-INA, 17 de junio de 2010, considerando $7^{\circ}$. 


\section{Polít. Crim. Vol. 16, № 31 (Junio 2021), Art. 7, pp. 164-196. [http://politcrim.com/wp-content/uploads/2021/05/Vol16N31A7.pdf]}

los que fijen el alcance de los delitos imprudentes de homicidio y lesiones. Así, el planteamiento de Duttge es contradictorio, puesto que, por una parte, rechaza cualquier determinación interpretativa de los delitos imprudentes, ya que ello se apartaría de la determinación legal que exige el párrafo 2 del art. 103 la Grundgesetz, y, por otra, termina abrazando la primera forma de determinación de aquellos delitos, al inclinarse por una exégesis conforme a la Constitución. ${ }^{122}$

\subsubsection{La necesaria inconstitucionalidad (también) de los delitos dolosos de homicidio y lesiones}

Finalmente, si la teoría de la indeterminación fuera acertada, no solo los delitos de homicidio y lesiones imprudentes serían inconstitucionales por infringir el mandato de determinación, sino también los dolosos. ${ }^{123}$ Esta consecuencia, difícilmente aceptable, se fundamenta en que la imprudencia no representa frente al dolo un aliud, sino un minus. ${ }^{124}$ Tanto las modalidades dolosas de los delitos de homicidio y lesiones, como las modalidades culposas, presuponen un comportamiento contrario a un deber jurídico que rige para una situación concreta. Mientras en las primeras el sujeto capta por completo la dimensión de injusto típicamente relevante de su comportamiento y, pese a ello, se decide en contra del bien jurídico, en las segundas modalidades el individuo yerra respecto de esa dimensión. Sin embargo, más allá de esa diferencia en la actitud interna frente a la infracción del deber de conducta que rige para un caso concreto, esta contravención representa el presupuesto básico común del injusto de los delitos de homicidios y lesiones, sean estos dolosos o imprudentes.

Pues bien, la ley penal es igual de "indeterminada" en los delitos dolosos de homicidio y lesiones, que en los culposos, puesto que en ninguno de ellos el legislador describe los deberes de conducta que rigen para situaciones determinadas, y cuya infracción puede generar responsabilidad penal. Así, verbigracia, es cierto que el Código Penal alemán no señala en el $\S 222$ que el quebrantamiento de la prohibición de manipular torpemente un arma de fuego, ocasionando un resultado de muerte, puede fundar una responsabilidad criminal; pero tampoco el $\S 212$ indica que la infracción del deber de no disparar repetidas veces con una pistola en el tórax de una persona permite el castigo a título de homicidio doloso. Si se considera que el $\S 222$ es inconstitucional por no precisar que la manipulación imprudente de armas de fuego, ocasionando la muerte de otro, cumple el tipo, lo mismo debería concluirse respecto del $\S 212$, que no indica que la acción de disparar varias veces en el pecho de una persona, provocando su muerte, satisface el tipo de homicidio doloso consumado.

Por otra parte, incluso si se entendiera, como lo hace un sector importante de la doctrina, ${ }^{125}$ que la imprudencia representa frente al dolo un aliud, y no un minus, uno debería también afirmar (si la teoría de la indeterminación estuviera en lo cierto) no solo la inconstitucionalidad de los homicidios y lesiones culposos, sino también de los dolosos, puesto que el tenor literal de estos últimos es igual de "indeterminado" que el que emplean las formas culposas. Así, la expresión "quien mate a una persona" ( $\$ 212 \mathrm{StGB}$ ) no ofrece

${ }^{122}$ Confróntese KIRSCH (2014), p. 165, incluyendo nota al pie 226.

${ }^{123}$ Confróntese HERZBERG (2011), pp. 448 y ss.

${ }^{124}$ En este sentido, entre otros, FREUND y ROSTALSKI (2019), § 7 nm. 39; FREUND (2019), p. 10; MURMANN (2017), § $30 \mathrm{~nm} .4$.

${ }^{125}$ Véase, por todos, JESCHECK y WEIGEND (1996), p. 563; RENGIER (2017), § 52 nm. 2. 
un grado de precisión mayor que la locución "quien cause a través de imprudencia la muerte" de otro (\$222 StGB). ${ }^{126}$

Por las razones expuestas, la teoría de la indeterminación de los delitos imprudentes de homicidio y lesiones previstos en los $\S \S 222$ y 229 del Código Penal alemán tiene que ser rechazada; en consecuencia, estos ilícitos cumplen el mandato constitucional de determinación. ${ }^{127}$

\section{La constitucionalidad de los delitos imprudentes de homicidio y lesiones en el Código Penal chileno}

La teoría de la indeterminación de los delitos imprudentes de homicidio y lesiones no solo tiene que ser rechazada en el contexto de los $\S \S 222$ y 229 del Código Penal alemán, sino también en el marco de los arts. 490, 491 y 492 de nuestro Código, en relación con los correspondientes delitos de homicidio y lesiones. ${ }^{128}$

Para explicar por qué "la conducta" a la que alude el inc. final del art. $19 \mathrm{n}$ " 3 de la Constitución Política está expresamente descrita en nuestros tipos imprudentes de homicidio y lesiones, y, por tanto, por qué estos satisfacen el mandato de determinación, conviene hacer una aclaración inicial. En los arts. 490, 491 y 492 del Código Penal chileno existe un sistema de castigo de la imprudencia de número abierto, y que rige respecto de ciertos delitos contra las personas, en concreto: el homicidio simple (art. $391 \mathrm{n}^{\circ} 2$ ), las lesiones graves (art. 397) y las lesiones menos graves (art. 399). ${ }^{129}$ Esto significa que en Chile los tipos de homicidio y lesiones culposos se construyen poniendo en relación los enunciados legales de los arts. 490, 491 y 492, con los enunciados de los arts. 391 n², 397 y 399, todos del CP. ${ }^{130}$ De este modo, combinando todas esas normas, se configuran cuatro tipos de homicidio imprudente (490; 491 , inciso $1^{\text {o }}$; 491 inciso $2^{\circ}$; y 492 inciso $1^{\circ}$, cada uno de ellos en relación con el art. 391 $\mathrm{n}^{\circ}$ 2), ocho tipos de lesiones graves imprudentes (490; 491, inciso $1^{\text {o; }} 491$ inciso $2^{\circ}$; y 492 , inciso $1^{\circ}$, cada uno de ellos en relación con los números 1 y 2 del art. 397) y otros cuatro tipos de lesiones menos graves imprudentes $\left(490 ; 491\right.$, inciso $1^{\circ} ; 491$ inciso $2^{\circ} ;$ y 492 , inciso $1^{\circ}$, cada uno de ellos en relación con el art. 399). La explicación de por qué los delitos imprudentes de homicidio y lesiones cumplen en Chile el mandato de determinación supone distinguir, entonces, entre tres grupos de tipos penales.

\footnotetext{
${ }^{126}$ Confróntese KREMER-BAX (1999), p. 16, incluyendo nota al pie 26.

${ }^{127}$ En este sentido, entre otros, FREUND y ROSTALSKI (2019), $§ 5$ nm. 3; FREUND (2019), pp. 12 y s.; JESCHECK y WEIGEND (1996), p. 564; HERZBERG (2011), p. 451; ROXIN (2013), p. 135.

${ }^{128}$ Partidario de la constitucionalidad en Chile de los delitos imprudentes de homicidio y lesiones BUSTOS (1995), p. 21, así como VAN WEEZEL (2011), p. 5.

${ }^{129}$ El sistema de número abierto solo rige respecto de estos tres delitos contra las personas, puesto que los restantes ilícitos previstos en el Título VIII del Libro II del Código Penal (parricidio, castración, etc.) exigen dolo directo. Véase, en este sentido, BUSTOS (1995), p. 19.

${ }^{130}$ Así lo ha destacado nuestro Tribunal Constitucional en rol 2154-11-INA, 14 de junio de 2012, considerando $31^{\circ}$.
} 


\section{Polít. Crim. Vol. 16, № 31 (Junio 2021), Art. 7, pp. 164-196. [http://politcrim.com/wp-content/uploads/2021/05/Vol16N31A7.pdf]}

\subsection{Los tipos penales de homicidio imprudente}

Los cuatro tipos penales de homicidio imprudente tienen en común el comportamiento consistente en "matar" a otro. ${ }^{131}$ La diferencia entre los cuatro tipos radica solo en la clase de imprudencia requerida ("imprudencia temeraria" en el caso del art. 490, "negligencia o descuido culpable" en el caso del art. 491, incisos $1^{\circ}$ y $2^{\circ}$, y "mera imprudencia o negligencia con infracción de reglamentos" tratándose del art. 492, inciso $1^{\circ}$ ) y en el sujeto activo (innominado en el caso de los arts. 490 y 492, inciso $1^{\circ}$, y nominado tratándose del art. 491, incisos $1^{\circ}$ y $2^{\circ}$ ).

Como ya vimos, la Constitución chilena exige que la norma legal de sanción establezca, con una precisión suficiente, la clase o género de infracciones a normas de conducta que ha de ser castigadas a través de una pena. Ese grado de determinación se alcanza cuando la norma de sanción permite reconocer el bien jurídico que protegen las normas de conducta cuya vigencia ha de ser estabilizada por medio de la pena. Los cuatro tipos de homicidio imprudente previstos en el CP cumplen con esta exigencia. En efecto, el comportamiento consistente en "matar" alude, inequívocamente, a un conjunto de conductas que infringen prohibiciones o mandatos específicos, que tienen por objeto proteger, todas ellas, la vida humana independiente. Por consiguiente, el ámbito del injusto punible es definido claramente por el legislador, vinculando de un modo efectivo a los jueces y evitándose así delegaciones subrepticias en la decisión democrática acerca de las conductas que merecen reproche penal.

Por otra parte, el que los tres tipos de homicidio imprudente, previstos en el Código Penal chileno, no le indiquen al ciudadano qué comportamientos tiene que ejecutar $\mathrm{u}$ omitir en casos concretos, a fin de eliminar o disminuir peligros para la vida, no significa en caso alguno que estos delitos sean indeterminados. Como ya se destacó, la función de las normas de sanción penal no consiste en establecer programas de minimización de riesgos para bienes jurídicos, sino en otorgar al juez un fundamento habilitante para declarar la culpabilidad del autor, e imponerle una pena.

El Tribunal Constitucional ha señalado que el tipo de homicidio imprudente del art. 492 inciso $1^{\circ}$, en relación con el art. $391 \mathrm{n}^{\circ} 2$, ambos del CP, cumple el mandato de determinación, puesto que describe el "núcleo de la conducta punible". ${ }^{132}$ Sin perjuicio de lo problemático de la idea del "núcleo de la conducta" como criterio para establecer si el legislador cumple o no con la exigencia constitucional de taxatividad, ${ }^{133}$ el Tribunal acierta en despejar cualquier duda sobre una posible indeterminación del tipo chileno de homicidio imprudente.

\footnotetext{
${ }^{131}$ Los tipos de homicidio imprudente que se construyen poniendo en relación los arts. 490, 491 (incisos $1^{\circ}$ y $2^{\circ}$ ) y 492, por una parte, con el art. $391 \mathrm{n}^{\circ} 2$, por otra, son los siguientes: "el que por imprudencia temeraria mate a otro"; "el médico, cirujano farmacéutico, flebotomiano o matrona que por negligencia culpable mate a otro"; "el dueño de animales feroces que, por descuido culpable de su parte, mate a otro", y "el que con infracción de los reglamentos y por mera imprudencia o negligencia mate a otro".

132 Véase sentencias rol 2154-11-INA, 14 de junio de 2012, considerandos $31^{\circ}$ y $32^{\circ}$, y rol 2716-14-INA, 10 de septiembre de 2015, considerando $34^{\circ}$.

133 Véase 1.2.2.
} 


\subsection{Los tipos penales de lesiones graves imprudentes}

En los ocho tipos penales de lesiones graves imprudentes, el comportamiento del sujeto activo consiste en "herir, golpear o maltratar de obra" a otro. También en estos tipos se cumple el mandato constitucional de determinación, puesto que en ellos se precisa detalladamente la clase o género de infracciones culposas a normas de conducta que tiene que ser castigadas.

El Tribunal Constitucional chileno ha declarado que el tipo de lesiones graves imprudentes del art. 492 inciso $1^{\circ}$, en relación con el art. $397 n^{\circ} 1$, ambos del CP, satisface la exigencia de determinación, al describir el "núcleo de la conducta punible". ${ }^{134}$

Por otra parte, como los comportamientos previstos legalmente en los delitos de lesiones menos graves imprudentes son los mismos que los contemplados en las formas dolosas de estos lícitos, la afirmación de la constitucionalidad de los primeros implica, obviamente, que los segundos también son suficientemente determinados.

\subsection{Los tipos penales de lesiones menos graves imprudentes}

Finalmente, los cuatro tipos penales de lesiones menos graves imprudentes también cumplen el mandato de taxatividad, aunque en ellos no se describan formas de conducta específicas, como sí ocurre con las lesiones graves, y solo se aluda al resultado de daño a la salud individual. Y es que, tal como ocurre con el $\S 229$ StGB, los tipos penales chilenos de lesiones menos graves culposas establecen, con precisión suficiente, la clase de infracciones a deberes jurídicos que tiene que ser castigadas a través de una pena: ha de tratarse del quebrantamiento de normas de conducta que tengan por objeto eliminar o disminuir hasta límites tolerados riesgos para la salud individual. En el caso de los tipos penales chilenos de lesiones menos graves imprudentes se exige, además, que se esté frente a conductas o a resultados distintos a los que prevé el art. 397 del CP. ${ }^{135}$

\section{Conclusión}

La pregunta que se planteó al comienzo de este trabajo, concerniente a si la regulación de los delitos imprudentes de homicidio y lesiones, contemplada en el Código Penal chileno, cumple el mandato constitucional de determinación, tiene que ser respondida afirmativamente. Como se explicó, el inc. final del art. 19 n³ de la Constitución Política exige que los tipos penales describan con suficiente precisión la clase o género de infracciones a normas de conducta cuya vigencia ha de ser estabilizada por medio de la pena. Los distintos tipos imprudentes de homicidio y lesiones, que se construyen poniendo en relación los enunciados legales de los arts. 490, 491 y 492, con los enunciados de los arts. 391 n ${ }^{\circ}$ 2, 397 y 399, todos del Código Penal, establecen de manera precisa la clase o género de infracciones a deberes jurídicos que pueden dar origen a responsabilidad penal. Por consiguiente, el ámbito del injusto punible en estos delitos es definido claramente por el

\footnotetext{
${ }^{134}$ Véase sentencia rol 2154-11-INA, 14 de junio de 2012 , considerandos $31^{\circ}$ y $32^{\circ}$.

135 Confróntese BUSTOS (1995), p. 35.
} 
Polít. Crim. Vol. 16, No 31 (Junio 2021), Art. 7, pp. 164-196.

[http://politcrim.com/wp-content/uploads/2021/05/Vol16N31A7.pdf]

legislador, vinculando de un modo efectivo a los jueces, y evitándose así delegaciones subrepticias en la decisión democrática acerca de las conductas que merecen reproche penal. 


\section{Bibliografía citada}

ALEXY, Robert (1986): Theorie der Grundrechte (Frankfurt am Main, Suhrkamp).

BUSTOS, Juan (1995): El delito culposo (Santiago, Editorial Jurídica de Chile).

COLOMBI, Aurelia (2005): Fahrlässigkeit und Tatbestandsbestimmtheit, Deutschland und Italien im Vergleich (Köln, Carl Heymanns Verlag).

CONTRERAS, Lautaro (2012): Normative Kriterien zur Bestimmung der Sorgfaltspflichten des Produzenten (Berlin, Duncker \& Humblot).

CURY, Enrique (1988): La ley penal en blanco (Bogotá, Temis).

DANNECKER, Gerhard (2007): "§ 1 Keine Strafe ohne Gesetz", en: LAUFHÜTTE, Heinrich Wilhelm; RISSINGVAN SAAN, Ruth; TIEDEMANN, Klaus (eds.),

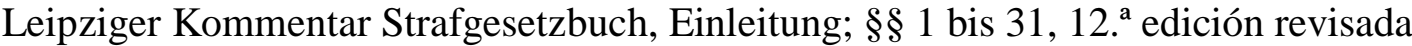
(Berlin, Walter de Gruyter). Disponible en: https://www.degruyter.com/view/db/lko [fecha de consulta: 28 de junio de 2019].

DUTTGE, Gunnar (2001): Zur Bestimmtheit des Handlungsunwerts von Fahrlässigkeitsdelikten (Tübingen, Mohr Siebeck).

DUTTGE, Gunnar (2003): "Fahrlässigkeit und Bestimmtheitsgebot", en: HIRSCH, Hans Joachim; WOLTER, Jürgen; BRAUNS, Uwe (ed.), Festschrift für Günter Kohlmann zum 70. Geburtstag (Köln, Dr. Otto Schmidt), pp. 13-35.

DUTTGE, Gunnar (2014): "Wider die Palmströmsche Logik: Die Fahrlässigkeit im Lichte des Bestimmtheitsgebotes”, en: Juristenzeitung (N6), pp. 261-270.

DUTTGE, Gunnar (2017): "StGB § 15 Vorsätzliches und fahrlässiges Handeln", en: JOECKS, Wolfgang; MIEBACH, Klaus (eds.), Münchener Kommentar zum Strafgesetzbuch, 3. ${ }^{a}$ edición revisada (München, C.H. Beck). Disponible en: https://www.beck-online.beck.de [fecha de consulta: 28 de junio de 2019].

ENGISCH, Karl (2010): Einführung in das juristische Denken, 11. a edición (Stuttgart, Kohlhammer).

ETCHEBERRY, Alfredo (1998): Derecho penal, Parte General, $3^{\text {a }}$ edición (Santiago, Editorial Jurídica de Chile), tomo I.

FERNÁNDEZ, José Ángel (1998): "La naturaleza y contenido del mandato de lex certa en la doctrina del Tribunal Constitucional español", en: Revista de Derecho (Valdivia) $\left(\mathrm{N}^{\circ} 1\right)$, pp. 141-151.

FERNÁNDEZ, José Ángel (2014): “Tribunal Constitucional y Derecho penal: un estudio crítico", en: Estudios Constitucionales (N²), pp. 187-238.

FERNÁNDEZ, José Ángel (2017): “La interpretación conforme con la Constitución en los límites del mandato de certeza”, en: Revista chilena de Derecho (Vol. 44, N³), pp. 653-675.

FISCHER, Thomas (2018): Strafgesetzbuch mit Nebengesetzen, 65. a edición (München, C.H. Beck).

FREUND, Georg (2007): "Die Definitionen von Vorsatz und Fahrlässigkeit, Zur Funktion gesetzlicher Begriffe und ihrer Definition bei der Rechtskonkretisierung”, en: HETTINGER, Michael; HILLENKAMP, Thomas (eds.), Festschrift für Wilfried Küper zum 70. Geburtstag (Heidelberg, C.F. Müller), pp. 63-82.

FREUND, Georg (2013): "Nicht „entweder - oder“", sondern „,weder - noch“ - Zum Versto $\beta$ gesetzesalternativer Wahlfeststellung gegen Art. 103 II GG”, en: ZÖLLER, Mark A.; HILGER, Hans; KÜPER, Wilfried; ROXIN, Claus (eds.), Gesamte 
Strafrechtswissenschaft in internationaler Dimension - Festschrift für Jürgen Wolter zum 70. Geburtstag am 7. September 2013 (Berlin, Duncker \& Humblot), pp. 35-59. FREUND, Georg (2015): "Verfassungswidrige Dopingstrafbarkeit nach § 95 Abs. 1 Nr. 2a AMG, Ein Beitrag zum Gesetzlichkeitsgrundsatz (Art. 103 Abs. 2 GG)", en: BANNENBERG, Britta; BRETTEL, Hauke; FREUND, Georg; MEIER, BerndDieter; REMSCHMIDT, Helmut; SAFFERLING, Cristoph (eds.), Über allem: Menschlichkeit, Festschrift für Dieter Rössner (Baden-Baden, Nomos), pp. 579-599. FREUND, Georg (2019): "Determinación legal de la punibilidad en los delitos imprudentes", en: Revista de Estudios de la Justicia ( $\mathrm{N}^{\circ} 31$ ), pp. 1-15. Disponible en: https://rej.uchile.cl/index.php/RECEJ/article/view/55754 [fecha de consulta: 28 de junio de 2019].

FREUND, Georg; ROSTALSKI, Frauke (2015): "Wesentliche Inhalte und Ergebnisse der Tagung „Strafrechtliche Verantwortlichkeit für Produktgefahren“ (18.-20. Juli 2013, Marburg)", en: FREUND, Georg; ROSTALSKI, Frauke (eds.), Strafrechtliche Verantwortlichkeit für Produktgefahren (Frankfurt am Main, Peter Lang), pp. 9-22.

FREUND, Georg; ROSTALSKI, Frauke (2016): "Gesetzlich bestimmte Strafbarkeit durch Verordnungsrecht?, Rückverweisungsklauseln als Versto $\beta$ gegen das Delegationsverbot aus Art. 103 II, Art. 104 I 1 GG”, en: Goltdammer's Archiv für Strafrecht ( $\left.\mathrm{N}^{\circ} 7\right)$, pp. 443-454.

FREUND, Georg; ROSTALSKI, Frauke (2019): Strafrecht Allgemeiner Teil, 3. a edición revisada (Berlin, Springer).

FRISCH, Wolfgang (1983): Vorsatz und Risiko (Köln, Carl Heymanns).

FRISCH, Wolfgang (1993): "Wesentliche Strafbarkeitsvoraussetzungen einer modernen Strafgesetzgebung", en: ESER, Albin; KAISER, Günther; WEIGEND, Ewa (Eds.), Von totalitärem zu rechtsstaatlichem Strafrecht. Kriminalpolitische Reformtendenzen im Strafrecht osteuropäischer Länder. Internationales Symposium in Buchenbach bei Freiburg vom 27.-31. Mai 1992 (Freiburg, Max-Planck-Institut für ausländischesund internationales Strafrecht), pp. 251-253.

FRISCH, Wolfgang (2011): "Zur Bedeutung von Schuld, Gefährlichkeit und Prävention im Rahmen der Strafzumessung", en: FRISCH, Wolfgang (editor), Grundfragen des Strafzumessungsrechts aus deutscher und japanischer Sicht (Tübingen, Mohr Siebeck), pp. 3-26.

GARCÍA, Mercedes (1993): "Remisiones normativas, leyes penales en blanco y estructura de la norma penal", en: Estudios penales y criminológicos ( $\left.\mathrm{N}^{\circ} 16\right)$, pp. 65-103.

GRÜNWALD, Gerald (1964): “Bedeutung und Begründung des Satzes „,nulla poena sine lege“", en: Zeitschrift für die Gesamte Strafrechtswissenschaft (Vol. 76), pp. 1-18.

HASSEMER, Winfried; KARGL, Walter (2017): "§ 1", en KINDHÄUSER, Urs; NEUMANN, Ulfrid; PAEFFGEN, Hans-Ulrich (eds.), Nomos Kommentar, Strafgesetzbuch, 5. ${ }^{\text {a }}$ edición (Baden-Baden, Nomos), pp. 191-270.

HERZBERG, Rolf Dietrich (2005): "Wann ist die Strafbarkeit „gesetzlich bestimmt" (Art. 103 Abs. 2 GG)?”, en: HEFENDEHL, Roland (ed.), Empirische und dogmatische Fundamente, kriminalpolitischer Impetus, Symposium für Bernd Schünemann zum 60 Geburtstag (Köln, Carl Heymanns), pp. 31-69.

HERZBERG, Rolf Dietrich (2011): "Die Fahrlässigkeit als Deliktsvoraussetzung und das Bestimmtheitsgebot (Art. 103 Abs. 2 GG)", en: Zeitschrift für Internationale Strafrechtsdogmatik ( $\left.{ }^{\circ} 5\right)$, pp. 444-452. 
HERZBERG, Rolf Dietrich (2015): "Strafrechtliche Fahrlässigkeit und Grundgesetz, Darf der Täter einer fahrlässigen Tötung nach $§ 222$ StGB bestraft werden?”, en: FAHL, Christian; MÜLLER, Eckhart; SATZGER, Helmut; SWOBODA (eds.), Festschrift für Werner Beulke zum 70. Geburtstag (Heidelberg, C.F. Müller), pp. 419-435.

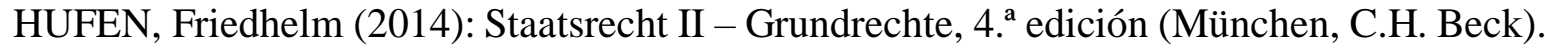
JAKOBS, Günther (1991): Strafrecht Allgemeiner Teil - Die Grundlagen und die Zurechnungslehre, 2. ${ }^{\mathrm{a}}$ edición (Berlin, Walter de Gruyter).

JESCHECK, Hans-Heinrich; WEIGEND, Thomas (1996): Lehrbuch des Strafrechts, Allgemeiner Teil, 5. a edición (Berlin, Duncker \& Humblot).

JOECKS, Wolfgang; MIEBACH, Klaus (eds.) (2017): Münchener Kommentar zum

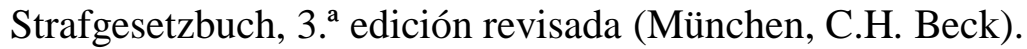

KARGL, Walter (2019): Strafrecht, Einführung in die Grundlagen von Gesetz und Gesetzlichkeit (Baden-Baden, Nomos).

KIRSCH, Florian Alexander (2014): Zur Geltung des Gesetzlichkeitsprinzips im Allgemeinen Teil des Strafgesetzbuchs (Berlin, Duncker \& Humblot).

KRAHL, Matthias (1986): Die Rechtsprechung des Bundesverfassungsgerichts und des Bundesgerichtshofs zum Bestimmtheitsgrundsatz im Strafrecht (Art. 103 Abs. 2 GG) (Frankfurt am Main, Peter Lang).

KREMER-BAX, Alexandra (1999): Das personale Verhaltensunrecht der Fahrlässigkeitstat (Frankfurt am Main, Peter Lang).

KUHLEN, Lothar (2006) Die verfassungskonforme Auslegung von Strafgesetzen (Heidelberg, C.F. Müller).

KUHLEN, Lothar (2007): "Zum Verhältnis vom Bestimmtheitsgrundsatz und Analogieverbot", en: DANNECKER, Gerhard; LANGER, Winrich; RANFT, Otfried; SCHMITZ, Roland; BRAMMSEN, Joerg (eds.), Festschrift für Harro Otto zum 70. Geburtstag am 1. April 2007 (Köln, Carl Heymanns Verlag), pp. 89-105.

KUHLEN, Lothar (2013): "Das Gesetzlichkeitsprinzip in der deutschen Praxis", en: HILGENDORF, Eric (ed.), Das Gesetzlichkeitsprinzip im Strafrecht (Tübingen, Mohr Siebeck), pp. 45-65.

LAGODNY, Otto (1996): Strafrecht vor den Schranken der Grundrechte (Tübingen, Mohr Siebeck).

LENCKNER, Theodor (1968): "Wertausfüllungsbedürftige Begriffe im Strafrecht und der Satz ,nulla poena sine lege“", en: Juristische Schulung (Fascículo 7), pp. 304-310.

MATUS, Jean Pierre; RAMÍREZ, María Cecilia (2015): Lecciones de Derecho penal chileno, Fundamentos y límites constitucionales del Derecho penal positivo, $3^{\mathrm{a}}$ ed. (Santiago, Legal Publishing).

MATUS, Jean Pierre; RAMÍREZ, María Cecilia (2019): Manual de Derecho penal chileno. Parte general (Valencia, Tirant lo Blanch).

MISSERONI, Adelio (1993-1994): "El principio de tipicidad en la Constitución de 1980", en: Revista de Derecho de la Universidad Católica de Valparaíso ( $\left.{ }^{\circ} 15\right)$, pp. 207230.

MURMANN, Uwe (2017): Grundkurs Strafrecht, $4^{a}$ edición (München, C.H. Beck).

NAVARRO, Irene (2010): Mandato de determinación y tipicidad penal (Granada, Comares). OSSANDÓN, Magdalena (2009): La formulación de tipos penales: valoración crítica de los instrumentos de técnica legislativa (Santiago, Editorial Jurídica de Chile). 
PUPPE, Ingeborg (2017): "Vor $\S \S 13$ ff”, en: KINDHÄUSER, Urs; NEUMANN, Ulfrid;PAEFFGEN, Hans-Ulrich (eds.), Nomos Kommentar, Strafgesetzbuch, 5. ${ }^{\mathrm{a}}$ ed. (Baden-Baden, Nomos), pp. 513-650.

RANSIEK, Andreas (1988): Gesetz und Lebenswirklichkeit (Heidelberg, v. Decker).

RANSIEK, Andreas (2008): "Bestimmtheitsgrundsatz, Analogieverbot und § 370 AO", en: SIEBER, Ulrich; DANNECKER, Gerhard; KINDHÄUSER, Urs; VOGEL, Joachim; WALTER, Tonio (eds.), Strafrecht und Wirtschaftsstrafrecht, Dogmatik, Rechtsvergleich, Rechtstatsachen, Festschrift für Klaus Tiedemann zum 70. Geburtstag (Köln, Carl Heymanns Verlag), pp. 171-188.

REMMERT, Barbara (2017): “Abs. 2 Art. 103”, en: HERZOG, Roman; SCHOLZ, Rupert; KLEIN, Hans; HERDEGEN, Matthias (eds.), Grundgesetz Kommentar, 81. ${ }^{a}$ entrega (München, C.H. Beck), pp. 1-112.

RENGIER, Rudolf (2017): Strafrecht, Allgemeiner Teil, $9^{a}$ edición (München: C.H. Beck).

ROXIN, Claus (2006): Strafrecht, Allgemeiner Teil, Grundlagen, Der Aufbau der Verbrechenslehre, $4^{\mathrm{a}}$ edición (München, C.H. Beck), tomo I.

ROXIN, Claus (2013): "Der Grundsatz der Gesetzesbestimmtheit im deutschen Strafrecht", en: HILGENDORF, Eric (ed.), Das Gesetzlichkeitsprinzip im Strafrecht (Tübingen, Mohr Siebeck), pp. 113-139.

SCHMITZ, Roland (2010): "Nullum crimen sine lege und die Bestrafung fahrlässigen Handelns", en: JOECKS, Wolfgang; OSTENDORF, Heribert; RÖNNAU, Thomas; ROTSCH, Thomas; SCHMITZ, Roland (eds.), Recht - Wirtschaft - Strafe, Festschrift für Erich Samson zum 70. Geburtstag (Heidelberg, C.F. Müller), pp. 181-198.

SCHMITZ, Roland (2017): "StGB § 1 Keine Strafe ohne Gesetz", en: JOECKS, Wolfgang; MIEBACH, Klaus (eds.), Münchener Kommentar zum Strafgesetzbuch, 3. ${ }^{a}$ edición revisada (München, C.H. Beck). Disponible en: https://www.beck-online.beck.de [fecha de consulta: 28 de junio de 2019].

SCHÜNEMANN, Bernd (1978): Nulla poena sine lege? (Berlin, Walter de Gruyter).

SILVA BASCUÑÁN, Alejandro (2006): Tratado de Derecho constitucional, $2^{\mathrm{a}}$ ed. (Santiago, Editorial Jurídica de Chile), tomo XI.

TIMM, Frauke (2012): Gesinnung und Straftat, Besinnung auf ein rechtsstaatliches Strafrecht (Berlin, Duncker \& Humblot).

VAN WEEZEL, Alex (2011): La garantía de tipicidad en la jurisprudencia del Tribunal Constitucional (Santiago, Legal Publishing Chile).

VERDUGO, Mario; PFEFFER, Emilio; NOGUEIRA, Humberto (1997): Derecho constitucional, $2^{\mathrm{a}}$ ed. (Santiago, Editorial Jurídica de Chile), tomo I.

VIVANCO, Ángela (2007): Curso de Derecho constitucional, $2^{\mathrm{a}}$ ed. (Santiago, Ediciones Universidad Católica de Chile), tomo II.

WALTHER, Susanne (2005): “Anmerkung zu BGH, Urteil v. 1.2.2005 - 1 StR 422/04”, en: Juristenzeitung $\left(\mathrm{N}^{\circ} 13\right)$, pp. 686-688.

\section{Jurisprudencia citada}

Corte Suprema, rol: 2285-2010, 10 de marzo de 2011.

Tribunal Constitucional alemán, BVerfGE 26, 41, 14 de mayo de 1969.

Tribunal Constitucional alemán, BVerfGE 28, 175, 15 de abril de 1970.

Tribunal Constitucional alemán, BVerfGE 41, 314, 11 de febrero de 1976. 
Tribunal Constitucional alemán, BVerfGE 71, 108, 23 de octubre de 1985.

Tribunal Constitucional alemán, BVerfGE 75, 329, 6 de mayo de 1987.

Tribunal Constitucional alemán, BVerfGE 87, 209, 20 de octubre de 1992.

Tribunal Constitucional alemán, BVerfGE 92, 1, 10 de enero de 1995.

Tribunal Constitucional, rol: 559-06, 7 de junio de 2007.

Tribunal Constitucional, rol: 781-07-INA, 27 de septiembre de 2007.

Tribunal Constitucional, rol: 1281-08-INA, 13 de agosto de 2009.

Tribunal Constitucional, rol: 1351-09-INA, 20 de mayo de 2010.

Tribunal Constitucional, rol: 1584-09-INA, 17 de junio de 2010.

Tribunal Constitucional alemán, BVerfGE 126, 170, 23 de junio de 2010.

Tribunal Constitucional, rol: 2154-11-INA, 14 de junio de 2012.

Tribunal Constitucional, rol: 2716-14-INA, 10 de septiembre de 2015.

Tribunal Constitucional, rol: 2758-14-INA, 10 de septiembre de 2015.

Tribunal Constitucional, rol: 2773 (2817, 2849 y 2859)-15-INA, 28 enero de 2016.

Tribunal Constitucional, rol: 2800-15-INC, 8 de marzo de 2016.

Tribunal Constitucional, rol: 3306-17-INA, 16 noviembre de 2017.

Tribunal Constitucional, rol: 3115-16-INA, 18 de julio de 2017.

Tribunal Constitucional, rol: 3630-17-INA, 17 de mayo de 2018.

Tribunal Constitucional, rol: 3329-17-INA, 23 agosto de 2018.

Tribunal Constitucional, rol: 5304-18-INA, 27 de junio de 2019. 